NBER WORKING PAPER SERIES

\title{
HUMAN CAPITAL AND FERTILITY IN CHINESE CLANS BEFORE MODERN GROWTH
}

\author{
Carol H. Shiue \\ Working Paper 19661 \\ http://www.nber.org/papers/w19661 \\ NATIONAL BUREAU OF ECONOMIC RESEARCH \\ 1050 Massachusetts Avenue \\ Cambridge, MA 02138 \\ November 2013
}

Earlier versions of this paper was presented at the University of California-Davis, Fudan University, University of Hong Kong, Hong Kong University of Science and Technology, Mannheim, University of Montreal, McGill, Northwestern, Oxford, Warwick, the Asian Historical Economics Conference, the NBER Development of the American Economy, the NBER Economic Fluctuations and Growth, and the Stanford SITE Conference. I thank Sascha Becker, Steve Broadberry, Raquel Fernandez, Avner Greif, Bishnupriya Gupta, Murat Iyigun, Wolfgang Keller, Omer Moav, Tom Rawski, Ted Telford, Michèle Tertilt, and Nathan Sussman for comments and discussions. T. Telford provided data used in this paper. Generous support from the Russell Sage Foundation and the National Institute of Child Health and Human Development (R03 HD042731-01) is gratefully acknowledged. The paper was partly written while the author was National Fellow at the Hoover Institution, whose hospitality is gratefully acknowledged. The views expressed herein are those of the author and do not necessarily reflect the views of the National Bureau of Economic Research.

NBER working papers are circulated for discussion and comment purposes. They have not been peerreviewed or been subject to the review by the NBER Board of Directors that accompanies official NBER publications.

(C) 2013 by Carol H. Shiue. All rights reserved. Short sections of text, not to exceed two paragraphs, may be quoted without explicit permission provided that full credit, including $(\mathbb{C}$ notice, is given to the source. 
Human Capital and Fertility in Chinese Clans Before Modern Growth

Carol H. Shiue

NBER Working Paper No. 19661

November 2013, Revised December 2013

JEL No. I25,J11,O15

\begin{abstract}
$\underline{\text { ABSTRACT }}$
A stylized fact of modern growth is that as countries become richer, education levels rise while family size decreases. This paper provides evidence that well before the onset of modern growth, changes in the return to education affected household choice of children's quantity versus quality. The setting is in Anhui Province, China over the 13th to 20th centuries. I show that the civil service examination system underwent long-term changes affecting the return to education, providing a means to test whether incentives for acquiring education affected fertility decisions. Employing an intergenerationally-linked dataset drawn from over 43,000 individuals, I first show that as the state examination's discretionary practices had been largely eliminated by the 17th century, increasing the return to education, households with a lower number of children had a higher chance that one of their sons would substantially invest into human capital. Second, I demonstrate that this negative relationship between fertility and education disappeared with a fall in the return to education due to the deterioration of the state examination system in the 19th century. Taken together, my findings provide support for the hypothesis that fertility choices respond to changes in the return to human capital. The implications of these findings for theories of economic development are discussed.
\end{abstract}

Carol H. Shiue

University of Colorado

Department of Economics

Boulder, CO 80309

and Stanford University Hoover Institution

and also NBER

carol.shiue@colorado.edu 


\section{Introduction}

The historical development of countries around the world shows that sustained increases in per-capita income coincide with increasing skills and education per worker. Human capital is seen as one the most important determinants of economic development in the growth experience of the United States, Britain, as well as other countries (Crafts 1995; DeLong, Goldin, and Katz 2003; Galor and Weil 2000, Galor and Moav 2002). Today, the World Bank, as the largest external supporter of education in developing countries, manages a portfolio of $\$ 11.1$ billion, spanning 71 countries. $^{3}$ The implications of this turn on the relationship between the number of children (fertility) and the education of each child (human capital). Here I ask whether the child quantity-quality relationship responds to economic incentives. ${ }^{4}$

Specifically, I examine the extent to which families responded to incentives to invest in human capital in a sample of families consisting of over 43,000 individuals in central China between the years 1300 and 1900. A simple model predicts that the choice between fertility and education depends on their relative returns. Empirically, the increase in the return to education by the $17^{\text {th }}$ century led to a robust negative relationship between education and fertility, while the decline of the return to education was accompanied by the disappearance of this negative relationship. This increase and subsequent decrease for child quality supports the hypothesis that economic factors help to determine the relationship between fertility and education in pre-industrial China.

Incentives to invest in human capital were spurred by the national civil service examinations, which the Qing state (1644 to 1911) used as an entry mechanism to determine who could be allowed to hold office in government. The examination consisted of a series of written tests that required a high level of literary skills and sophisticated knowledge of an extensive curriculum, requiring many years of study in order to master. Although civil service examinations were used already in the Song dynasty (960-1127), over most dynasties the recruitment of officials did not rely

\footnotetext{
${ }^{3}$ World Bank (2014).

${ }^{4}$ Starting with the work of Gary Becker (1960) economists have pursued the idea that fertility is based on rational choice; Becker (1981) discusses the implications of a rise in the demand for human capital on the parental choice of the quality and quantity of offspring. On its broader importance for economic development, see Galor (2011).
} 
exclusively, or even predominately, on this route. For much of the history of the civil service examination system, other channels of advancements co-existed with it. For example, during the Ming (1368-1644) the purchase of offices and titles, and discretionary appointments were very common channels of entering the elite group of high-ranking officials.

By the time of the reign of the first Qing emperor Shun-zhi (1644-1661) the civil service examination system had become the predominate pathway to elite status, attaining its final form which is today most typically associated with the institution. While certain degrees were offered for purchase at one time or another, and especially during times of revenue deficit, such as during the Taiping Rebellion (1850-64), these degrees were given different names. The higher-rank degrees that would allow the holder to obtain significant titled positions were much more exclusive than the purchased titles and moreover indicated the holder had passed the national examinations (Ho 1962). One reason why previous and more discretionary channels of entering officialdom became less common for the Han Chinese may have been that the Qing emperors, who were ethnically Manchu rulers, were concerned with establishing legitimacy of the new dynasty and control over local elites. Thus, in the early Qing, the examination system was the primary channel of gaining political influence and high social status.

During the $19^{\text {th }}$ century, the state examination system deteriorated rapidly. ${ }^{5}$ While it is difficult to isolate all the factors responsible for this decline, the exam system became more discretionary, and the increase in population relative to the number of official positions meant that the competition in the exams increased (Ho 1962; Elman 2002; Miyazaki 1976). This led to a decline in the expected return to education, most likely reinforced by a decline in the state's per-capita tax revenues that lowered the returns of being a state official upon successfully passing the exam and obtaining a position.

In this paper, I contribute to the literature by providing evidence that fertility responded to economic incentives: namely, that incentives to acquire human capital, as defined by whether a man participates in the examinations, produced a significant negative relationship with the size of the family in which he was raised. Specifically,

\footnotetext{
${ }^{5}$ Yuchtman (2014) studies the transition from the declining state examination system to a Western education system towards the end of the Qing dynasty (1911).
} 
from the $17^{\text {th }}$ to $18^{\text {th }}$ centuries, among the elite families in which both the father and grandfather were educated, an additional brother is associated with a 0.04 percentage point decline in the probability of participating in the examinations. Evaluated at the mean of the participation rate for this group, 0.34 , this implies that an additional brother contributes to a $12.2 \%$ decline in exam participation. The relationship is also negative and significant for men who had neither an educated father nor grandfather, showing that this quantity-quality relationship was not confined to elite groups but applied to a large social spectrum. I also present support for a positive effect of reduced fertility on higher education using instrumental-variables estimation for a smaller sample of men.

This negative relationship between fertility and education during the $17^{\text {th }}$ and $18^{\text {th }}$ century by itself does not imply that households chose the number of children in response to education goals. Fertility differences could be determined by resource differences, health shocks, or famines, for example, and given variation in the number of children a negative quantity-quality relationship could be the result of a resource constraint—child quantity crowds out quality. This concern is addressed in two ways. First, I use information on a range of resource, health, demographic, and aggregate factors, showing that the negative relationship between fertility and education remains present even after plausible determinants of fertility variation other than parental choice have been controlled for. Second, and arguably more importantly, I show that there was a decline in the return to education after 1800 that led to the disappearance of the negative child quantity-quality relationship in China.

The implication is striking because demographic patterns in China have traditionally stressed women's early age at marriage, universal marriage for women, large families of rich men, and son preference-all patterns which suggest that economic incentives matter little for fertility, and certainly not for sons. ${ }^{6}$ Some of these conclusions have recently been questioned, with some authors suggesting that there may have been deliberate fertility control before the year 1970 (Zhao 1997) or even starting in the $18^{\text {th }}$ century (Campbell and Lee 1997). ${ }^{7}$ By shifting the focus from fertility as such to the link between human capital and fertility, my work sheds new light on a mechanism central to

\footnotetext{
${ }^{6}$ Coale (1985); Lavely and Wong (1998); Lavely (2007); Wolf (2001).

${ }^{7}$ On this debate, see Wolf (2001), Zhao (2002), and Campbell, Feng, and Lee (2002).
} 
economic development, and by analyzing several additional centuries I am able to show not only that a negative child-quantity quality relationship existed but that it responded to long-term changes in the economic incentive to become educated.

Because aggregate-level data masks important heterogeneity determining historical human capital-fertility relationships (Guinnane 2011), together with a recent but rapidly expanding literature I employ more disaggregated data. ${ }^{8}$ Becker, Cinnirella, and Woessmann $(2010,2012)$, in particular, use detailed county-level data to show that a fertility-education trade-off existed in $19^{\text {th }}$ century Prussia. I extend this literature by exploiting variation across intergenerationally-linked households over a long sample period, which is key to providing evidence on the fertility-education trade-off from longterm changes in the return to education.

Another contribution of this paper is to shift the focus from Europe to China, where less is known on the timing and the cause of fertility declines. Generally, fertility decline has often been depicted as arising after the onset of the era of modern growth around 1800, and has been linked to changes in child mortality, demand for children, women's' work, public schooling, child labor and other factors (Doepke 2004, Lee 2003, Easterlin and Crimmins 1985). In counterpoint to Western developments, during the period studied in this paper China was a pre-modern economy experiencing few of these changing social and institutional developments that have been associated with fertility decline in the Western experience. ${ }^{9}$ My findings for China emphasize that a relatively high demand for human capital is critical for the quantity-quantity tradeoff to emerge, not modern economic growth as such. Furthermore, the trend towards lower human capital and higher fertility during the Late Qing might help to explain that China fell behind Western Europe during the late $18^{\text {th }}$ to $19^{\text {th }}$ centuries.

\footnotetext{
${ }^{8}$ Fernihough (2011) shows that school enrollment declines with sibship size in early 20 th $c e n t u r y$ Ireland; Klemp and Weisdorf (2012) document that marital fecundity, instrumented by time-until-first-child, is associated with lower literacy of the offspring in reconstitution data for $18^{\text {th }}$ and $19^{\text {th }}$ century England; Basso (2012) examines the effect of child education on parents' fertility across early $20^{\text {th }}$ Spanish provinces; and Murphy (2015) shows that family size is negatively correlated with measures of education across late$19^{\text {th }}$ century French regions.

${ }^{9}$ For example, after Newcomen and Watt pioneered the steam engine in $18^{\text {th }}$ century Britain, by the $1830 \mathrm{~s}$ the first railway lines were being constructed in Germany as well as the United States. Between 1825-1850, markets in Europe were much more integrated than they were just 50 years earlier, suggesting that the roots of modernization had taken hold (Shiue and Keller 2007). Also printing and the Enlightenment might have affected the timing of growth in Europe (Mokyr 2012).
} 
Finally, this paper contributes to the literature employing Chinese genealogies as a source of data (Liu 1978, 1980, 1992, Fei and Liu 1982, Telford 1986). While as I discuss below genealogies have certain limitations compared to high-income country census data (Harrell 1987, Telford 1990, Zhao 1994), the possibility of linking multiple generations is a key advantage, especially on questions where long-run dynamics could be important, such as the inter-generational transmission of human capital (discussed below). Most of the existing work employing genealogies to date focuses on questions in demography; by examining the relationship between fertility and education, this paper sheds new light on the potential of using genealogies for studying key economic questions.

The organization of the paper is as follows: Section 2 provides historical background on education from the Yuan (1271-1368), the Ming (1368-1644), and Qing Dynasties (1644-1911), with emphasis on the costs and the potential returns to education. Section 3 introduces a theoretical framework that guides the empirical analysis. Section 4 discusses the data and provides descriptive statistics on my sample from the Tongcheng area, in Anhui Province. This section also discusses in greater depth the extent to which the data compiled from genealogical evidence, and in particular the Tongcheng genealogies, can be taken as representative of the population at large. I consider issues of sample selection, recall bias, and survivor bias. To the extent that this is feasible, I present evidence from other sources as a check of the external validity of the Tongcheng genealogies, finding that the Tongcheng sample provides a valid characterization of key dimensions of the population. The reader is also referred to additional tables in the Appendix. The main empirical results are in section 5. Section 5.2 provides evidence on a negative quantity-quality relationship during the early Qing period, defined as 16441800. Section 5.3 shows that this negative relationship disappeared towards the end of the Qing as the return to participating in the state examinations declined. Section 6 concludes with a discussion of the implications of these findings. 


\section{The Ming-Qing educational system and state sponsored civil-service examinations}

This section provides information on China's state sponsored civil-service examinations. I begin by showing that the state examinations became the country's central element of human capital formation and path to upward mobility.

\section{Eligibility and scope: from discretion to rules}

The essence of the civil service examination system was that it required a high level of education as a prerequisite for appointment to government office. It was an institution that was shaped over a long period spanning several dynasties. The first step towards it occurred during the Tang Dynasty (670-906 AD), when hereditary aristocracies were largely eliminated. ${ }^{19}$ However, even though literacy and knowledge of the classic texts were prerequisites for appointment, the examination process was a much simpler affair that relied first and foremost on the discretionary recommendations of candidates near the capital (Teng Ssu-yu 1967, pp. 25-49; Chaffee 1985, pp. 14-15, 182), and so the pool of candidates was in effect highly constrained. In addition, up until the end of the Song Dynasty, circa 1279, artisans and merchant families were not legally eligible from the standpoint of sumptuary laws to participate in state examinations (Ho 1962, p. 41).

For many centuries thereafter, examinations and discretionary appointment existed side-by-side. Examinations were effectively used in conjunction with ad hoc appointments of officials all the way to the Ming (1368-1644), because many men could purchase degrees, rather than passing written examinations, as an equally valid channel to high office. According to Ho Ping-ti (1962): “All the way down to the end of the Ming period "chien-sheng" (holders of a purchased degree) were legally and institutionally entitled to government office." Between the years 1406 and 1574, Ho (1962) also gives records of appointees that indicate more than half of the high level candidates that had obtained their office from these unorthodox or irregular channels that involved purchases of degrees. $^{20}$

\footnotetext{
${ }^{19}$ For further discussions on social mobility in China during the late imperial era, see Greenhalgh (1988). The use of a civil service examination for government service was also used in Western countries, but only much later. England adopted a government service examination in 1870, and the U.S. in 1883 (Miyazaki 1976, 124).

${ }^{20}$ A series of decrees, starting in 1451 in the Ming dynasty, formally permitted men without academic
} 
Large gaps in the administration of examinations can be found in the Ming-in the late $14^{\text {th }}$ century, fourteen years lapsed between one exam and the next, providing additional evidence that the state did not rely exclusively on exams as the means of recruiting officials. ${ }^{21}$ Consistent with the general lax attitude of the state towards examinations during this period, the number of people who could acquire a licensing degree (the sheng-yuan degree and equivalents) was loosely controlled. Through the late $16^{\text {th }}$ century, there were no limitations on the number of these degrees that could be newly awarded each year in the larger counties (Ho 1962, p. 178). The overall effect was one of sharply fluctuating numbers across different regions of new degrees, depending on the discretion of the local education commissioner. There were also strong overall increases in the early $17^{\text {th }}$ century, in part due to the fact that counties were simply selling the degrees outright (ibid p. 178). ${ }^{22}$ Under these circumstances of mixed incentives and discretionary degree awards, one would not expect to find a consistent rational response to investments in child education.

It was not until the mid- $17^{\text {th }}$ century, when renewed efforts to overhaul the system made the returns to education more predictable. The changes were not all made at once, but the cumulative effect was such that by the end of the reign of the first Qing emperor, in 1661, the civil service examination system was quite different from what it had been up to that time in essentially important ways (Elman 1994). These changes were crucial in raising the legitimacy of the civil service examinations, and turning it into the key channel of entry into elite status. ${ }^{23}$

Examinations were also regularly administered throughout the Qing Empire. The discretionary fluctuations of the late Ming were stabilized in the $17^{\text {th }}$ century when the first Qing emperor Shun-zhi (1644-1661) issued a 1661 decree that reset quotas for each

degrees to purchase their way towards appointment to high level offices (Ho 1962, pp. 32-33).

${ }^{21}$ The first Ming national exam was given in 1371, wherein 119 degrees were given. The second exam was given only 14 years later, with 485 degrees awarded (Elman 2000, 68; Ho 1962, 186).

${ }^{22}$ One estimate suggests that the actual number of these degrees increased by 20 -fold nationally from the late 1500 s to 1600 (Ho 1962, 182).

${ }^{23}$ By about 1650 , the only types of hereditary privileges and automatic status that remained belonged to the imperial lineage where the throne was passed from the emperor to one of his sons and the families of the Eight-Banner system. Indeed, whereas the provinces had provincial quotas, the Banner families had a generous "Banner" quota. The latter was an exclusive hereditary institution that dominated military and command functions, and men born into banner families held a caste-like elite position. Elliot (2001) estimates the total banner population in the early $18^{\text {th }}$ century was $3 \%$ of the population of China, most of whom resided in Beijing and Manchuria. 
prefectural city and county in so far as the number of new licensing degrees that could be issued at each examination. ${ }^{24}$ Unlike the Ming state, the Qing government was much more serious in enforcing the upper limits (in the form of quotas) of new degrees issued, especially at the basic entry level, or the licensing level (the sheng-yuan degree). ${ }^{25}$ Since only people with a licensing degree obtained through written exams could be considered for the upper level examinations, the enforcement of lower level quotas thereby reinforced education rather than discretion in the system (Ho1962, 182). Variations in the number of sheng-yuan degrees during the first two centuries of the Qing period were minor (Ho 1962, 179). ${ }^{26}$

Crucially complementing this policy, other means for entering officialdom were heavily closed off for the Han Chinese majority population, so that discretionary appointments declined sharply and purchased appointments were vanity titles that did not confer the same elite status as examination degrees. ${ }^{27}$ The civil service examination system became a much more predictable institution, with a higher expected return to human capital, certainly relative to what had come before it. As I discuss below, this would change again towards the end of the Qing.

\section{Costs and returns to education}

This section shows that both costs and returns to education in China were substantial, and they were borne by private agents. There were major differences between basic literacy training and investments in civil service. Anecdotal accounts of teacher salaries suggest the costs of schooling to attain basic literacy during the Qing

\footnotetext{
${ }^{24}$ In 1661 maximal quotas for the numbers of eligible candidates per year were 20 for a large prefectural city, 15 for a large and "cultured" county, and 4-5 for a small and "backward" county. Daqinghuidian shili (1899 edition) Ch. 370.

${ }^{25}$ There were multiple levels of degrees that could be earned, with the lower level acting as a gateway into entry into higher degrees. There were three major categories: the licentiate status (sheng-yuan)--a lower level degree given to men who passed the initial exam at the local (prefectural or county) level. The degree was necessary for further attempts to advance. An intermediate degree (at the provincial level), was known as the ju-ren; it was significant from an official standpoint because it would allow the individual to be appointed to a minor official office. It was necessary in turn for attainment of the jin-shi degree (the national exam), which entitled the candidate to high-ranking positions in the bureaucracy.

26 "In all likelihood the fluctuations in the total cumulative number of sheng-yuan in an average lifetime during the first centuries of the Qing period were not very great...All in all, the Qing state succeeded in the main in keeping a stable sheng-yuan quota system." (Ho 1962, p. 197)

27 The Qing also sold titles at various points, but only temporarily. The most notable episode of sales did not occur until the revenue difficulties of the Taiping Rebellion of 1850's and 1860's. Also, the Qing preserved a distinction between earned degrees and purchased titles. Purchasers of titles did not enjoy the same privilege and power as high office through passing the exams.
} 
period were modest. Parents of even moderate means could pool together tuition fees to hire a local schoolmaster-drawn from the pool of men who tried but were unsuccessful in the imperial exams - to teach village youngsters basic literacy in return for room and board, meals, and a small allowance (Ebrey 1993, p. 72); other types of support might be had from the lineage. At times teachers had to do other tasks because of their low pay (Ho 1962, p. 140). It is estimated that around 30-45 percent of males and 2 percent of females were literate in the late Qing (Rawski 1979, p. 23). Over three or four years, children could learn approximately 1,000 characters, which was sufficient to be able to read business contracts and vernacular text (Leung 1994, p. 393; Ebrey 1993, p. 348).

Much more time and effort than for basic literacy was required to prepare for the imperial examinations, which required memorization of vast tracts of literary and historical material and the ability to write in a highly stylized fashion. The state examinations took place in stages, much like a tournament. Literate men were nominated at the county level for candidacy to the first level examinations. Those who succeeded in this initial exam were licentiates (sheng-yuan), and were eligible to consider the next stage of examinations, which would qualify the candidate for official appointments. Candidates as young as 15 years were known to pass these licensing examinations, but most were in their twenties (Elman 2000, 263). Estimates place the number of licentiates in the nation in 1700 at 500,000 (perhaps $0.3 \%$ of the population).

Evidence of the costs of higher education can be seen in the private academies established in the $18^{\text {th }}$ century, which allowed teaching and classical research to be alternative careers to government appointment. Unlike teachers for youngsters, these teachers may have been elites who held degrees themselves; some may have been retired officials who had returned home after their civil service career.

The fee for taking the metropolitan examinations during the $16^{\text {th }}$ century is estimated to be around 833 silver dollars, a large amount (Miyazaki 1976, p. 118). For comparison, it is estimated that the literati (those who were literate in the classics and therefore could enter teaching careers) had food, shelter, and an average annual income of 778 silver dollars in the $19^{\text {th }}$ century (Elman 2002, p. 403).

While the state established the content and curriculum for the official examinations, the decision of whether or not to groom a son for his preparation for civil service was a 
private investment decision. Typically, this education had to start early, when the boy was very young (Miyazaki 1976). Because of the large number of characters that had to be memorized, it was a consuming effort. Mandatory education did not exist at any level through the period under study. Although the imperial government issues decrees that schools be set up in prefectures and counties, in practice, teachers and schools were largely funded through private initiatives organized at the local level. ${ }^{28}$ Because schooling was neither mandatory nor regulated, a wide variety of schools could be found, with some kind of school present in most villages and urban centers (Rawski 1979, p. 17; Leung 1994). Specialized schools, and officially subsidized schools, such as the schools specializing in military education of medicine, or national schools that were open to students preparing for state exams, could also be found. Private institutions also flourished-academies such as those established by salt merchants of Guangzhou, for example, may have allowed their sons to receive the best schooling of the empire (Elman 2002, pp. 403-06). In the Qing, although the government also set up prefectural schools, these were stations for licentiates (those men who had already passed the qualifying exam) for collecting subsidies, rather than places where learning took place (Elman 1991). ${ }^{29}$

For the most part only those men with a fortunate family background could take advantage of this system of entering officialdom. However, at least in principle, the system was a meritocracy in which non-elites could not be barred from the examinations. The old sumptuary laws that discriminated against artisans and merchants had long been abolished by this time, and all men, regardless of their family background, could legally take part in the examinations. Especially gifted boys could rise in a rags-to-riches way through the ranks and there were men of legendary brilliance who did so (Elman 2000, p. 263). Generally, however, the sons of the upper class families had much better opportunities and much greater resources to receive the schooling and tutoring that was required for exam preparation. Although women were barred from state service, upper class girls also received lessons and were literate. For elite boys, schooling likely began earlier than for most, at the age of 5, often first with their mother and then with hired

\footnotetext{
${ }^{28}$ For instance in the year 1078, it was decreed that provinces and prefectures should appoint full-time school teachers, but only 53 counties out of 1000 counties did so. (Ho 1962, p. 170). At the start of the Ming (1368-1644) another decree to establish schools was issued, with more compliance (ibid, p. 179).

${ }^{29}$ Basic state support came in a 1382 decree, which entitled licentiates to tax exemptions for themselves and two males in the family and a basic amount of rice (Ho 1962, p. 172).
} 
tutors (Elman 1991, pp. 16-17).

By the Qing, provincial exams were given in the provincial capital every three years, and were scheduled over a period of nine days. ${ }^{30}$ Exam questions were based on the moral and political thinking of classicism, and required candidates to compose poems and essays. The exams were not exclusively humanist, however, and included also policy questions on statecraft, fiscal policy, as well as military and political institutions at the time. ${ }^{31}$ The question of the usefulness of the knowledge that was tested at the official exams is a subject worthy of study in its own right. For the purposes of this paper the content of the exams is not directly relevant. What is important is that there were potentially large returns for investments in education, and that these investments were not small.

Those who passed these exams were already eligible for official appointments, but they could also choose to take the next level examinations, the metropolitan examinations, which took place in further rounds. At the conclusion of those exams a list of the successful candidates was produced, in rank order. Graduates of these exams enjoyed an extremely high reputation. For those who received official degrees, their subsequent position as an official of the Qing state enabled them to amass a relatively high income (Chang 1962, p. 3). This income, derived from both formal and informal sources, enabled the government official to have a relatively high living standard, contribute to local community projects, and make investments in landed property. It has been noted that an official position in the government offered some of the most financially rewarding careers available, and that the prestige and power that came with such positions was unmatched (Elman 2000, p. 292). Merchants who had accumulated fortunes could on occasion purchase minor titles and thus buy into some part of the governing elite, but participation in the state exams was the direct route, and the only way to acquire higherlevel positions.

Since the state did not interfere with decisions on household investment activities or the number of children families should have, economic investments into education were

\footnotetext{
${ }^{30}$ Upwards of 4,000 persons appeared for provincial exams at the capital (Twitchett and Mote 1998, p. 36).

${ }^{31}$ For example, in the first metropolitan exam of the Qing dynasty in 1646, the regent asked how the government could bring Manchu and Han officials and people together for a common purpose. This was an important question for the Qing Manchu government that sought to rule over a Han Chinese population. See Twitchett and Mote (1998), Ch 7, p. 361.
} 
borne privately by the families of potential candidates. Education was thus costly, but it was also rewarding. Although children could not directly inherit official positions and titles, earned income could be passed on to descendants because of an economic environment of generally secure property rights combined with low taxation during the period under study.

In the early Qing period, the return to education in the form of lifetime income from official salaries and bonuses was significant and such individuals continued to enjoy prestige and high status. The annual salary of the head of the province (the governorgeneral) in the $18^{\text {th }}$ century, plus the expected official bonuses, informal gifts, and grain easily surpassed the value of 250,000 silver dollars. For the head administrator of the county (the district magistrate), the sum of informal bonuses and gifts alone would have amounted to about 45,500 silver dollars per year (Wakeman 1975, pp. 26-27).

\section{The incentives to acquire human capital over time}

As discussed above, during the $17^{\text {th }}$ century the Qing state established, much more successfully than any dynasty before it, a non-discretionary and merit-based state examination system. In this section I show that subsequent changes in the system during the period of 1800 and later (denoted as Late Qing) likely reduced the incentives to acquire human capital. These incentives would have depended on the expected return to human capital, net of the costs. ${ }^{32}$

On the benefit side of human capital acquisition, I will begin by discussing the return conditional on passing the state examinations. As noted above, passing the examinations was the primary pathway to becoming state official, with the income that came with it. There is information on the salary schedule of officials; in the $19^{\text {th }}$ century, a first-ranked official for example, which includes a Grand Secretary, would receive 180 taels per year, whereas a second-ranked official, such as a Vice-President of one of the Boards, would receive only 150 taels annually (Chang 1962, Tables 1,16$).{ }^{33}$ The main reason why it is

\footnotetext{
${ }^{32}$ The introduction of the printing press might have affected the costs of human capital acquisition (Becker and Woessmann 2009), in addition to diffusing knowledge relevant to merchants (Dittmar 2011). In China the introduction of movable type printing facilities in the early $16^{\text {th }}$ century had arguably limited effects. Ho notes that printed books were still too expensive relative to the means of the large majority of the population, to the point that the introduction of printing in fact increased the hold of high-status families on passing the higher state examinations (1962, pp. 214-215).

${ }^{33}$ Officials also received a varying allowance in terms of rice, given in Chang (1962, p.12).
} 
impossible to use information on the official salary schedule, which exists for all levels of official position, to obtain a Mincerian return to education schedule is that far more important than official salary was the extra income that came with the office, which while generally considered legitimate was not systematically recorded. The extra income for a Grand Secretary is estimated at annually 52,500 taels, e.g., and that of a Vice-President of a Board at 30,000 taels (Chang 1962, Table 16). This means that the official portion of the salary is about 0.3 and 0.5 percent, respectively, of the total income that these officials commanded.

In the absence of systematic data on the amount of the officials' extra income, the return to human capital can be estimated from information on the officials' life style and spending based on biographies, lineage genealogies, and local histories (gazetteers). ${ }^{34}$ The anecdotal evidence is consistent with a decline in the return to human capital during the Qing. For example, in the $18^{\text {th }}$ century a single retired official, Chiang Chi, spent 300,000 taels on constructing roads around his native place; Chiang Chi had the resources to do so because he served for ten years as official on the Board of Punishment. Comparably high sums during the $19^{\text {th }}$ century are not recorded (see Chang 1962).

Another part of the return to human capital came in terms of income from teaching, especially for those men who passed the exam but did not obtain an official position (students, sometimes for all their lives). The income of students clearly fell over time. During the Ming dynasty, students received generous stipends in form of food (two bushels of rice), cotton and silk cloth, embroidered silk cloth, as well as sets of clothing, headgear, and boots, travel money to go home to visit family. They were also given holiday money, grain to support their wives and children, money to pay for their wedding, and in addition two sets of women clothing (Ho 1962). In contrast, during the Qing students received only minimal grain stipend and tax exemptions from the state (Cong 2007). Towards the end of the Qing, the income from teaching was so low that in some cases teachers could not sustain themselves with it and instead died of hunger, such as Ch'in Ta-chang of Nanyang or Liu Lien-chung of Lu-i (Chang 1962, pp. 252, 254). Consistent with this, teachers' real wages fell by 50\% between the year 1700 and 1800 ,

\footnotetext{
${ }^{34}$ One important aspect of an official's spending were expected donations to his clan, or lineage (the temple, other buildings, or land). For example, in the 1880s the Huang lineage expected 1,000 taels per year from a lineage member who was Governor, and 200 taels from someone who was Prefect; Chang (1962, Table 7).
} 
and on average teachers' real wages were lower in the Late Qing, defined as post-1800, compared to the Early Qing period (see Rawski 1979, Figure 1).

Additional evidence for the decline of the return to human capital comes from data on private academies, which during the Qing were primarily concerned with preparing students for the state examinations (Ho 1962, 200). While during the period of 1662 to 1795 about 20 academies per one million of Guangdong's population were set up, during the period 1796 to 1908 this fell to 8 academies per one million people, less than half the earlier figure. ${ }^{35}$ To the extent that this decline in the expansion of preparatory schools for the state examinations reflects a lower demand for human capital, it is consistent with a decline in the return to human capital.

Finally, for any given return to human capital conditional on passing the state examination, the decision to invest into human capital was also affected by a candidate's chance to pass the examination. Given that the number of county seats, and thus magisterial and prefectural positions in the imperial China changed little-it was 1,385 in Ming and 1,360 in Qing — the number of official positions remained roughly constant. In contrast, the size of China's population had a strong upward trend. Estimates suggest the rate of growth was somewhere between $0.5 \%-1 \%$ per annum over the $14^{\text {th }}$ to $19^{\text {th }}$ centuries (Ho 1959, pp. 263-64; Perkins 1969, Table 4.a; Durand 1977; McEvedy and Jones 1978). Compounded over time, the absolute numbers reached 400-450 million by the late Qing from 140-150 million in 1700. As a consequence, the ratio of official positions relative to the size of population fell, and the resulting increase in the degree of competition arguably decreased the expected return to human capital further. ${ }^{36}$

Overall, the evidence supports the hypothesis that the return to human capital fell towards the later part of the Qing era. To the extent that this decline leads to lower levels of human capital in the population, this trend is evident in my sample. Between 1661 and 1700 , more than $14 \%$ of the married men are educated, followed by $6.5 \%$ between 1700 and $1750,5.1 \%$ between 1750 and 1800 , and $3.9 \%$ after the year 1800 .

\footnotetext{
${ }^{35}$ Based on data in Ho $(1962,201)$; my analysis includes both academies set up under official initiative and those set up under private initiative. I take 9.8 million to be Guangdong's average population for the 16621795 period, and 28.2 million for the 1796-1908 period, using Ho's population estimates (Ho 1962, p. 223).

${ }^{36}$ One might think that the return to office might rise with the increase to population size, although as discussed above there is no evidence for this. For evidence that competition was intensifying over the Qing across all regions of China, see Chang (1955), Ho (1962), Elman (2000, Table 3.4, 662).
} 
Having described the evolution of the state examination system, as well as the implications for the changing returns for human capital, I now turn to a simple theoretical framework in which to interpret these changes.

\section{Theoretical framework and testable implications}

The relationship between child quantity and quality is determined by the utilitymaximizing choice of households. Human capital formation will be affected by changes in the costs and benefits of child quantity versus quality. Let there be a household that derives utility $u$ from consumption $c$, the number of (surviving) children $n$, as well as from the quality (human capital) $h$ of those children. As in Galor and Weil (2000), Galor and Moav (2002), I assume that households maximize a log-linear utility function of the following form:

$$
u=(1-\gamma) \ln c+\gamma(\ln n+\beta \ln h),
$$

where $\gamma, 0<\gamma<1$, and $\beta, \beta<1$, are constant parameters. Expenditure is divided between the share spent on consumption goods, $(1-\gamma)$, and the share spent on children, $\gamma$. The parameter $\beta$ gives the preference for child quality. The household cares about human capital both because that may generate a revenue stream (in particular, if the child passes the government exam and obtains an official position) and perhaps for intrinsic reasons.

For each child, parents spend a fraction $\tau^{q}$ of their time budget (and a corresponding share of their potential income) on raising children. Furthermore, a fraction $\tau^{e}$ of parents' time is required for each unit of education of each child. The costs for raising one child with education $e$ thus are $\tau^{q}+\tau^{e} e$ units of time. Assuming that the potential income of the household working full-time is $y$, the household faces the following budget constraint:

$$
y\left(\tau^{q}+\tau^{e} e\right) n+c \leq y
$$


where the price of a child is the opportunity cost associated with raising it, $y\left(\tau^{q}+\tau^{e} e\right)$. Equation (2) confirms that both child quantity and child quality come at the expense of a lower consumption of goods.

Suppose that the level of human capital of each child, $h$, is an increasing, strictly concave function of the parental time investment in the education of the child, $e: h=h(e)$. Optimization yields

$$
n^{*}=\gamma /\left(\tau^{q}+\tau^{e} e^{*}\right)
$$

and

$$
e^{*}=e\left(\beta, \tau^{q}, \tau^{e}\right)
$$

where $n^{*}$ and $e^{*}$ denote the optimal choice of child quantity and quality, respectively. Equation (3) describes the trade-off between child quantity and quality.

The return to education varies inversely with $\tau^{e}$ because parents who do not spend time educating their offspring will produce with any $w$ units of time $w$ units of consumption goods. Equation (4) shows that the quantity-quality trade-off is affected by $\tau^{e}$; in particular, the optimal level of child quality increases as $\tau^{e}$ falls, and vice versa. This model yields the following predictions for my analysis: first, the cumulative changes up to the $17^{\text {th }}$ century made in the state examination system (as described above) can be interpreted as an increase in the expected return to human capital accumulation (lower $\left.\tau^{e}\right)$. Second, the decline in the expected return to human capital accumulation from the Early to the Late Qing (higher $\tau^{e}$ ), as discussed above, will decrease the optimal level of human capital investment.

This simple model can accommodate a number of extensions without changing the key prediction. First, differences in the productivity of the education process can be captured as follows. Let $\ln (h)=\delta^{\mathrm{t}} \ln (e), 0<\delta^{\mathrm{t}}<1$, where $t$ indexes a certain era, $t=$ early or $t=$ late. $^{38}$ If $\delta^{\text {early }}>\delta^{\text {late }}$, a decline over time has the same qualitative implications as a

\footnotetext{
${ }^{38}$ I define the Early Qing to be the years 1644 to 1800 , and Late Qing is post-1800. The sensitivity of the results with respect to these definitions is examined below.
} 
decline in the return to education: it reduces child quality. ${ }^{39}$ See also Moav (2005) who discusses the case where individuals' productivity as teachers increases with their own human capital while their productivity in simply raising children is not affected by their human capital levels. Second, the model assumes that all household investments in child education are in terms of time. As noted above, mothers often spent time on educating their sons. However, if households could also purchase education services at price $p^{e}$ (by hiring tutors), this would provide a reason why richer households acquire more education for their children. Nevertheless, as long as households need to spend some part of their time on child education, such as the time needed for the selection and monitoring of tutors, the model's prediction remains qualitatively unchanged.

In the following section I describe the data.

\section{Data}

The data of this paper comes from genealogies of individuals and households who lived in Tongcheng County of Anhui Province. Tongcheng County is approximately 30 miles by 60 miles, and is situated on the Yangzi River about 300 miles inland from the coast of the East China Sea. The county is about 150 miles from Nanjing, the early Ming Dynasty capital, and 650 miles from Beijing, the later Ming and Qing capital. Anhui Province was representative of the more developed and densely settled regions of China, with Tongcheng considered a centrally important economic region in the relatively developed agricultural economies of the lower Yangzi. The region was mainly a riceproducing area where the wealthiest families were typically landowning gentry (Beattie 1979, pp. 130-131). Over the Ming and Qing Dynasties, the region gained some fame for having produced a number of the highest officials of the empire.

The dataset is created from genealogies of seven lineages of Tongcheng County. ${ }^{40}$ Typically, genealogies start with the progenitor of the lineage from which all following lineage members descend. In the Tongcheng genealogies, the lineages' progenitor is recorded typically in the $14^{\text {th }}$ century, with the earliest date being the year 1298 . The

\footnotetext{
${ }^{39} \delta$ could also be stochastic due to idiosyncratic factors across individuals or over time.

${ }^{40}$ Instead of lineage, authors in the literature use terms such as clan, extended family, and common descent group.
} 
Tongcheng genealogies cover typically 18 consecutive generations, with a maximum of 21 . The latest death recorded in my data set is 1925 . Generally, the coverage of genealogies at the turn to and into the $20^{\text {th }}$ century becomes patchy (for example, see Harrell's 1987 analysis of Liu's 1992 lineage data from Taiwan). Telford gives as the coverage of the Tongcheng genealogies the years 1300 to 1880 (1990, p.124), which is by the standards of most socio-economic data an extraordinarily long period. ${ }^{41}$ While my sample covers part of the Yuan and the Ming dynasties the large majority of observations are for the Qing, see Figure 1.

The purpose of genealogies was to keep a record of the rituals of the family and a record of the achievements of its members. One important achievement was the acquisition of human capital for passing the state examinations. They were compiled and updated by the literate members of the lineage to aid in the ritual of ancestral worship. The genealogies were valued and kept in the hometown of the family in ancestral halls, providing future generations with a record of the location of graves, texts relating to grave worship, family rules of conduct, biographies of prominent members, a record of lineage lands, and an overall history of the family. ${ }^{43}$

\subsection{Chinese Genealogies as source for research}

Given their purpose and method of collection, genealogies do not completely match up to census data, official population registers, and other administrative data. Census data typically record the observed population at a certain date, either at the time of registration or in retrospect. One would need repeated observations throughout the lifetime of the same individual in order to determine the highest lifetime achievement of that person or household. By contrast, genealogical data presents one entry per person in biographical format. When the birth and death dates are given, the achievement listed in that individual's record can be considered the highest position achievement over the lifetime of the individual. In addition, the voluntary nature of data assembly of genealogies may induce selection, the retroactive updating of the genealogy might lead to

\footnotetext{
${ }^{41}$ The Tongcheng genealogies are not unique in the length of the period covered; Fei and Liu (1982), for example, examine ten lineages over the period of 1400 to 1900.

${ }^{43}$ Surveys of the content and scope of Chinese genealogies include Liu $(1978,1980)$ and Telford $(1986)$.
} 
recall bias, and there may also be survivor bias. I will consider these issues below. Genealogies cover men (and boys) better than women (and girls), being organized patrilineally--each male member of the lineage is a member. Furthermore, in terms of vital statistics, genealogies cover birth better than death.

Genealogies give a window to examine questions that are hard to address otherwise, in China or elsewhere. This is particularly true in cases where intergenerational linkages might play a role, as in the case of human capital accumulation. Census data in the U.S., for example, becomes available in the $19^{\text {th }}$ century; Long and Ferrie (2013) studies occupational mobility based on two generations, in 1850 and $1880 .{ }^{44}$ Chinese genealogies as a source have high potential because linking three, five, or even more generations would be straightforward. ${ }^{45}$ Registers that accurately record total population developments in China, such as Lee and Campbell's (1997) data from Liaoning province, become available only in the mid- $18^{\text {th }}$ century, and they cannot be used to answer certain questions because the data is by its very nature nonrepresentative. ${ }^{46}$ At the same time, major findings of genealogical research have been supported by simulation analysis (see Zhao 1994, p. 425).

The usefulness of genealogies for research depends on the questions asked. One important distinction is whether or not the primary goal of the research is to assess the entire population, with birth rates, death rates, and fertility rates derived from it. Along the same lines, Harrell (1987, p.73) contrasts research interested in obtaining accurate demographic measures from research seeking to make comparisons within the population of the genealogy. Clearly, underreporting matters if the main goal is to estimate population totals. My interest lies in examining how in this particular sample the relationship between education and fertility evolved over time. The extent to which certain limitations of genealogical data affect my estimate of the education-fertility relationship will be discussed below.

\footnotetext{
${ }^{44}$ See Collins and Wannamaker (2015) on intergenerational mobility in the late $19^{\text {th }}$ and early $20^{\text {th }}$ century U.S.,

45 The present study works with a three-generation linked sample; see Shiue (2015) for an analysis of intergenerational mobility using the Tongcheng genealogies.

${ }^{46}$ The Liaoning data is for the Han Army Eight Bannermen; they were a hereditary military elite concentrated in Northern China.
} 
There is a wide consensus that the Tongcheng genealogies are an extraordinarily strong source of this genre. This is the result of both the high-quality original material and also of the work that researchers have done to improve the original source. For example, in the original Tongcheng records, the year and month of the death for males is missing in only $19 \%$ of the cases (Telford 1990, p.124) while the typical figure is around $50 \%$ (Harrell 1987, p.76). The Tongcheng genealogies surpass the typical standards in other ways as well (see Telford 1986, 1990; Harrell 1987). Subsequently, the Tongcheng data has been enhanced by the estimation of vital dates using life tables and other wellknown methods (see Telford 1990). ${ }^{47}$ I have taking another step at improving the Telford data by eliminating a number of clerical and otherwise obvious errors.

The following section introduces the data and provides summary statistics for the estimation sample. I will also compare this Tongcheng data with other available information on China during this time.

\subsection{Sources of information in the Tongcheng data}

Generally, genealogies provide information on male lineage members, their wives, and their children. As is often the case, one can link the data across generations by tracing sons as they reappear in the genealogies as adult men. In the following I summarize the available information on the men, women, and children separately before turning to the inter-generationally linked sample on which the estimation results are based.

The unit of observation in my analysis is the household, defined by the male head of household. This nuclear household is often embedded in a broader family structure, at times consisting of co-residing grandparents and invariably reflecting lineage ties. ${ }^{48}$

\footnotetext{
${ }^{47}$ Life table and related demographic approaches were originally developed under the auspices of the United Nations. For applications on lineage populations, see Liu (1980), Harrell (1985); Telford (1990) extends their approach in a number of ways.

${ }^{48}$ Co-residence among younger and older generations was common practice during the Ming-Qing era. Tax census data for the late $18^{\text {th }}$ century suggests the average size of the household was anywhere from 5 to 8 persons, typically with the grandparents sharing a household with their sons and grandchildren (Wang 1974).
} 
The data gives information on a total of 9,787 men, all of who were over the age of 17. Around the year 1790, Tongcheng County had a population of approximately 1.3 million, suggesting that my sample covers about $1.5 \%$ of the Tongcheng population. ${ }^{49}$

Table A provides summary statistics for the 9,787 married men in my sample. The years of birth and death allows estimating life expectancy, which is 36 years for these men on average. It is above the life expectancy for all males (about 30 years in the $17^{\text {th }}$ and $18^{\text {th }}$ centuries) because all of these 9,787 men have survived childhood and have married. ${ }^{50}$

Table A also shows that for roughly seven percent of these men there is evidence of substantial levels of human capital, which is coded as Education $=1$ in the data. This measure of human capital is based on information contained in the genealogies on the level of education a man had achieved throughout his life. Since it required to acquire a substantial amount of human capital, I code Education to equal one if the man has passed one or more levels of official state examinations. Also official students (preparing for licentiate status), licentiates (sheng-yuan; preparing for the higher level exams), as well as men who prepared for (but failed) the examinations are coded with 1 for Education. ${ }^{51}$ Others are given a 0 for Education. The human capital coding is shown in Table 1; further, in section 5.2 I examine different levels of human capital separately.

Although licentiates, as well as those who prepared for the exams but failed, were not eligible for office, these men and their families would certainly have already made considerable investments in their education. The number of men in this group was large and included the 1-2 million men who sat for the licensing examinations every other year across the empire; we know they must have been educated, because they already had to have passed a series of pre-qualifying tests in their districts. In addition, men who prepared for but did not pass the exams should be considered as being educated because

\footnotetext{
${ }^{49}$ I observe about 3,600 men that would be alive in the year 1790 in my sample. These men had more than 4,200 wives, and the data records more than 7,500 sons and 4,100 daughters, for a total of just under 20,000 persons. Gazetteers were local histories about a certain place. Three county-level gazetteers about Tongchong cover the period under analysis: Tongcheng xian zhi (1490), Tongcheng xian zhi (1696), Tongcheng xuxiu xian zhi (1827).

${ }^{50}$ This life expectancy is comparable to life expectancies for largely agrarian economies. For example, England in the $18^{\text {th }}$ century (35-38 years), France in the late $18^{\text {th }}$ century (28 years), and Anhui Province, China from $14^{\text {th }}$ to $19^{\text {th }}$ centuries (28 years). See table 5.2 in Clark (2007).

${ }^{51}$ My education classification is based on Chang (1959, 1962), Ho (1962), and Telford (1995).
} 
they invested in the education, and we are mainly interested in the household investment aspect, and not just the outcome. Although success in the exams necessarily implies investments, many households made investments without succeeding in the exams because of the extremely low number of degrees awarded. Including only the men who succeeded in passing the examinations at the highest levels would not adequately capture the relationship between child quantity and quality.

While men who obtained purchased degrees are given a value of 0 for Education in the baseline analysis, given that they might have made substantial non-human capital investments to purchase this degree, which might have implications for fertility, I analyze those with purchased degrees below as well. The information on the men's education levels is related to the highest status levels obtained during their lifetime, which is also given in Table $1 .^{52}$

I am also interested in the human capital levels of the men's' fathers. More than $10 \%$ of the men had fathers with significant human capital levels (Education equal to 1), as reported in Table A. That father's education is on average higher than son's is due in part to a decline in the fraction of the population that was able to attain a government position over time. Table A also reports that these men had on average 1.17 wives; more than one wife can be seen as a measure of wealth of these men.

The average of 1.17 translates into the 11,378 women in my sample, for whom I report certain characteristics in the lower part of Table A. Multiple marriages are mostly due to the death of the spouse, occurring in about 12 percent of all marriages. ${ }^{53}$ The sample has information on the birth years and months of all wives in the sample. While the time of death is recorded less well than the time of birth, ${ }^{54}$ it is still available for the large majority $(78 \%)$ of all the wives. Based on the almost $60 \%$ of the wives for which there is information on the human capital of their fathers, these fathers are educated in $8 \%$ of the cases. The correlation between a man's own level of education and the education of his father-in-law is 0.37 . While the education level of the wife is unknown, it is reasonable to expect that the wife's human capital is increasing in that of her father. To

\footnotetext{
${ }^{52}$ Status ranges from 0 (no status) to 22 (highest status).

${ }^{53}$ Polygynous unions occurred in less than 2 percent of the cases.

${ }^{54}$ In part due to the fact that some individuals were still alive at the time the last version of the genealogy was published, in the early $20^{\text {th }}$ century; I will explore the role this plays below.
} 
the extent this is the case, my sample gives evidence on positive assortative matching in China starting with the Yuan dynasty.

The 11,378 wives correspond to an equal number of distinct couples in the sample, and I now turn to their children. There is information on 31,327 children from the 11,378 marriages of the 9,787 men (see Table B). Of these children, 20,177 are sons and 11,151 are daughters (64\% versus 36\%); more complete reporting on male than female children is typical of Chinese genealogies. The distribution of birth and death months suggests that the Tongcheng genealogies have a relatively high quality. In particular, one would expect that in large samples births and deaths are more or less uniformly spread out over the year, and the Tongcheng data gives roughly 6.5 as the mean death and birth months. Furthermore, looking at the parents from the children's point of view, note that the average age at death of the daughters' mother is close to the average age at death of the sons' mother (55.9 versus 55.7 years). The corresponding values for father's age at death are in fact identical for daughters and sons (55.4 years). The father's birth month of the sons is on average 6.5 , while it is 6.6 for the daughters. This shows that differential completeness in the reporting of sons and daughters need not introduce biases.

After summarizing information on men, women, and children, I now turn to the estimation sample. Linking an additional generation leaves 8,893 men for whom I have information on father and grandfather's education. Of these, $7 \%$ of the men live during Yuan and Ming times, just over 55\% in early Qing (1644-1800), and 38\% after the year 1800 , see Table 2.

About $6.3 \%$ of these men had significant levels of human capital (Education $=1$ ), and the average number of brothers was 3.3. Marital fertility rates depicting the average number of male births per woman per year by age that go along with that are shown in Figure 2. The fertility rates have the expected shape, dropping off with age and reaching zero by age $45-49$. While the date of marriage is unknown, the difference between the birth year of the wife and the birth year of her first recorded child indicates a relatively early marriage age for women in the sample. On average, the mother's age at birth is about 28 years. Both the relatively early marriage age and the age-specific fertility 
patterns are broadly consistent with other sources (Lee and Campbell, 1997) and what we would expect to be true biologically about fertility and age (Shryock and Siegal1973). ${ }^{55}$ The number of total siblings, boys and girls, is about 4.85 in my sample. The share of girls in total siblings is $27 \%$ in the sample, and about $10 \%$ of the men are from multiplewives household (Mother's rank not equal to one).

Comparing the different subperiods, note that the average level of education during Yuan and Ming times is relatively high. This is in part because lineages are sometimes established with a progenitor that is educated, and there are relatively few observations. In the analysis below the focus is largely on the post-1644 period.

Table $\mathrm{C}$ in the appendix shows summary statistics across the seven lineages in my sample, the Chen, Ma, Wang, Ye, Yin, Zhao, and the Zhou. The largest lineage in my data are the Wang, with about 4,700 of the married men, followed by the $Y e$ with around 1,600 men. While in many dimensions the differences across lineages are relatively small, they are different in terms of the average level of human capital. In particular, the $M a$ lineage is exceptionally well-educated, with one-third of the married adult men having extensive formal education, in the sense of Education equal to 1.

In addition, I report summary statistics separately by education level in Table 3. Educated men tend to be recorded earlier than not educated men, with mean birth years of 1728 and 1766, respectively. This reflects the fact that compiling a family history requires a certain level of skills. In contrast, there is no evidence that birth month differs between educated and non-educated men, which is expected but at the same time reassuring. Educated men live longer and have a larger number of wives than not educated men (columns 3 and 4, respectively). Furthermore, educated men have a higher number of siblings than not educated men as well as more educated fathers (columns 7 and 5, respectively). These are signs of resource and health differences across households.

At the same time, the number of male siblings for educated men tends to be smaller than for not educated men (column 6). This is consistent with a quality-quantity trade-off. The last two columns of Table 3 show some evidence on positive matching in the

\footnotetext{
${ }^{55}$ Studies of fertility in China at times apply a scaling factor to account for any under-recorded births (male and especially female). This would not affect the fertility-education relationship I focus on.
} 
marriage market. Wives of educated men live on average eight years longer than wives of not educated men, a difference which is even larger than for the men themselves.

Furthermore, while roughly one in three educated men have an educated father-in-law, among not educated men only one in twenty has an educated father-in-law (last column). These factors could play an important role in the human capital acquisition decision for different parts of the population.

In the next section I will compare this sample to other information on China, as well as address a number of specific concerns.

\section{The Tongcheng sample compared with other evidence}

One way to check whether the genealogies provide a representative sample of general demographic characteristics is to compare the Tongcheng data to other samples, while noting the respective selection issues. I analyze the Tongcheng sample along a number of dimensions. Comparing the Tongcheng data with that of the Liaoning Banner populations of Lee, Campbell, and Anthony (1995) for 1774 to 1873, one finds a similar variation in the probability of dying with age across the two populations (Telford 1990 Figure 2). The level of mortality is generally higher in the Tongcheng sample, especially for the 50 to 70 year olds. A plausible reason noted by Telford is the Taiping Rebellion (1850-64), which affected Tongcheng but not Liaoning because the rebels never got as far north as that province.

Returning to the fertility curves of Figure 2, are these rates consistent with fertility control to achieve education goals? Below I will show that the difference in the number of brothers between educated and non-educated men that are similar in many other respects is about 0.3 (see Table 7), so expected fertility in a controlled regime (i.e. when pursuing education goals) should not be very different from fertility when no educational goals are being pursued. Nevertheless, it is worth noting that women of the Ma lineage have comparatively low fertility rates when aged 20 to 30 years, while women of the Chen and Zhao lineages have comparatively high fertility when they are around 20 and 30 years old, respectively. Given that the $M a$ lineage is highly educated while the Chen 
and the Zhao lineages are the two least-educated lineages (see the averages in Table C), this is consistent with a deliberate choice of quality versus quantity.

The most systematic evidence on education in China during the Ming-Qing is related to the state examinations. In particular, the number of licentiates (sheng-yuan), individuals that passed the initial state examination, was about 500,000 in the year 1700 (Elman 2000), or roughly $0.3 \%$ of the population. In the Tongcheng sample, about $0.76 \%$ of the men alive around 1700 were licentiates. Accounting for women, children, and elderly indicates that the fraction of licentiates in Tongcheng was similar, or perhaps somewhat lower than that in China as a whole.

Moving up in terms of human capital to the highest degree holders (jinshi), in his seminal study on China-wide mobility, Ho (1962) reports that during the Qing in Anhui Province there were 41 jinshi per one million population, or, 0.0041 percent. The province of Anhui, it should be noted, was below the provincial average in terms of jinshi per capita in Qing China (Ho 1962, p. 228). In comparison, Tongcheng County in Anhui had 14 jinshi during the Qing as per my sample, which comes to about 0.045 percent of the population. ${ }^{57}$ Thus are about ten times more jinshi in my Tongcheng sample than in Qing Anhui overall.

While this suggests that Tongcheng had a higher level of education than Anhui's population on average, clearly, jinshi were rare, with many parts of Anhui not producing a single jinshi over centuries. The strong influence of aggregation in these comparisons becomes clear when noting that a single prefecture could have as many as 1,004 jinshi during the Qing (Ho 1962, p. 247). With seven counties to a prefecture, this means that the average county of that prefecture had 1,004/7 = 143 jinshi during the Qing, or an order of magnitude higher than the number of jinshi in Tongcheng county. Overall, while the number of men with the highest levels of human capital in Tongcheng was higher than in the local surrounding area, Tongcheng was not among the top human capital areas in China; rather, it was noteworthy at a local, perhaps provincial level.

\footnotetext{
${ }^{57}$ There are 8,291 married men during the Qing in the sample. To convert this into a population figure, I assume that $20 \%$ of all men did not marry, and that the Qing population was composed of below-age-ofmarry/men/women to one-third each. This gives a scaling factor of 3.75: $14 \mathrm{jinshi} /(8,291 \times 3.75)=0.045$ percent.
} 
Moreover, variation in jinshi across lineages in the Tongcheng sample dwarfs the difference between the sample variation in jinshi and what we know about the population. At the top of the list, the $M a$ lineage had 9 jinshi relative to 627 men, a ratio of $1.4 \%$, whereas other lineages in my sample do not have a single jinshi. As a consequence, sample variation across lineages can be used to assess the influence of status and sample composition on the results (see Table F).

We can also look at the representation of different status levels in the sample. While there exists no generally agreed-upon status classification for Qing China, in the Liaoning Eight Banner sample $98 \%$ of males had "No Status" while $2 \%$ were "Officials". 58 This compares to about $71 \%$ of men having "No Status" (status level 0) in the Tongcheng sample, while about $1.4 \%$ have an official position (as opposed to expectant). The relatively high fraction of "Officials" in the Eight Banner population might be related to the fact that it was a selected group. We know this was the case because the degree allotments and quotas for the Liaoning, which was the homeland of the ethnic Manchu rulers were higher than they were for the Han Chinese areas. The status distinction in the Eight Banner data set appears to be also sharper than what I consider here (see Table 1). This could help to explain why the fraction of "No Status" men in the Tongcheng sample is relatively low.

In sum, in terms of many characteristics potentially affecting the relationship between fertility and education, the Tongcheng sample is quite similar to what we know about China from other sources, and to the extent that there are differences they can be explained partially by certain observables. Overall, this suggests that the Tongcheng sample will be informative for the fertility-education relationship in China.

\section{Regression to the mean, recall bias, and survivor bias}

Variation across lineages is useful to examine a number of factors that could affect that a particular observation is included in the sample. First, genealogies often begin with a particularly noteworthy man, who then becomes the progenitor of the lineage. Part of his noteworthiness might come from a high level of education, and a

\footnotetext{
${ }^{58}$ Source: Author's computations from the China Multigenerational Dataset, Liaoning1749-1909, http://www.icpsr.umich.edu/icpsrweb/ICPSR/studies/27063.
} 
trend of declining education over time, as I will show below, might be related to that (regression to the mean).

In my sample, there are three lineages whose records begin with an educated progenitor, the Chen (progenitor born in 1298), the Wang (1358), and the Ma (1408). These three progenitors had an intermediate level of human capital, not high; they were Imperial students (see Table 1). For the other four lineages, the highest levels of education are typically found nine generations after the inception of the lineage. Controlling for lineage differences in average education, there is no evidence that typical education levels in a lineage fall in later generations. Thus, a simple regression-to-themean effect is unlikely to be important in driving my results. To further address this point I include different trend variables in the regression analysis (Tables 5 and E).

It may also be that the Tongcheng genealogy contains more records of educational success rather than failure (positive selection). I examine this in a number of ways. First, across the seven lineages the correlation between average education and the number of observations is -0.10 (not significant). Thus there is no evidence that on average, more successful lineages have included more entries in their genealogies.

A related concern is that periods during which a lineage is successful are those when relatively many lineage members are recorded. However, the correlation across lineages and generations is relatively small and negative (-0.07). The updating of the genealogy occurred retrospectively by the relatively resourceful lineage members. One might therefore believe that periods right after a lineage had been relatively successful are those when substantial resources would be devoted to updating the genealogy and the number of records would be high. However, the correlation of -0.04 between average education in the previous generation and the number of lineage members recorded in the Tongcheng genealogy does not confirm this.

Another concern is that strong groups of individuals tend to be overrepresented towards the end of the sample (survivor bias). It is well-known that Chinese genealogies deteriorate in their record keeping in the $20^{\text {th }}$ century (e.g. Harrell, 1987). While here this is not going to matter-the fraction of men in the sample alive in the twentieth century is less than $0.5 \%$--I have computed for each lineage the fraction of observations in the 
nineteenth century and later, versus before. If survivor bias is strong one would expect that lineages with high human capital achievements account for a relatively large share of the post-1800 observations in the data. However, a regression of the lineage's share of post-1800 observations on (the log of) the lineage's average education yields a coefficient of 0.018 (s.e. $=0.062, \mathrm{R}^{2}=0.02$ ). This suggests that a major survivor bias is unlikely.

Overall, based on this analysis the evidence for recall bias or other forms of selection bias is limited. I now move to the empirical analysis.

\section{Empirical results}

Section 5.1 provides evidence that the nature of the fertility-human capital relationship, as measured by the number of brothers and having prepared for or passed the state examinations, changed going from the Ming to the Qing era. Section 5.2 shows that there was a negative relationship between fertility and human capital acquisition during the early Qing (1644 to 1800), consistent with the quantity-quality framework laid out in section 3. Furthermore, instrumental-variables estimation for a subsample of men provides support that lower fertility has a positive causal effect on human capital accumulation. In Section 5.3 I show that the negative relationship between human capital accumulation and fertility disappeared towards the end of the Qing. The weakening of the child quantity-quality relationship is what would be expected when the return to human capital accumulation fell, as described in section 2.

\subsection{The fertility-human capital relationship from the Yuan-Ming to the Qing}

\section{Period}

I have shown in section 2 that from the early Ming the state examination system became more consistent over time. While no single change might have been decisive, cumulatively the changes meant that human capital accumulation turned into the most important reason for upward mobility in China. More changes took place during the $17^{\text {th }}$ century, in particular with dynastic change to the Qing dynasty (1644-1911). In what follows I will take the beginning of the Qing era as the dividing line. While this likely 
overstates the discreteness of changes affecting human capital accumulation, the dynastic change from the Ming to the Qing is a natural breakpoint.

The difference in the relationship between human capital and fertility between the Yuan-Ming and the Qing eras is summarized in Table 4. We see that a man without education had on average 2.7 brothers during the Yuan-Ming while with education he had typically about 3.1 brothers. That male fertility was higher for educated than for not educated men during the Yuan-Ming is also a statistically significant finding, as shown on the right side of Table 4. In contrast, during the Qing educated men had fewer brothers than non-educated men. This constitutes evidence for a change in the human capitalfertility relationship from the Yuan-Ming to the Qing. During the Qing, the fertility and human capital patterns in the sample are in support of a negative relationship between child quantity and child quality, whereas during the earlier period the data points to a positive relationship between child quantity and quality.

Furthermore, I find that the negative relationship between the number of brothers and education is stronger in the early than in the late Qing period. Restricting the analysis to men born during the Qing years 1644 to 1800 ("Early Qing” in Table 4), educated men have on average 0.35 brothers less than non-educated men, compared to 0.25 fewer for the entire Qing era (Table 4). This is initial evidence for a weakening of the quantityquality relationship towards the end of the Qing. I will return to this in section 5.3 below.

\subsection{The human capital-fertility relationship between 1644 and 1800}

This section examines the relationship between child quantity and quality during the early Qing period. I show that there is a negative relationship that is robust to including demographic, health, and resource determinants in the analysis. Section 5.2.1 probes into the robustness of this finding by considering shocks, lineage-specific trends, and heterogeneity across subpopulations and human capital levels. Further support for a negative relationship between child quantity and quality is provided with the instrumental-variables results for a subsample of men in Section 5.2.2. 
The model laid out in section 3 implies a negative relationship between child quantity $(n)$ and child quality (e); it is summarized in equation (3), which solving for $e$ can be rewritten as

(3') $\quad e=\frac{\gamma}{n \tau^{e}}-\frac{\tau^{q}}{\tau^{e}}$

In this section, I employ simple regression specifications to test for this negative relationship between $e$ and $n$ in my sample. Consider the following OLS specification:

$$
\text { Education }_{i}^{h l}=\beta_{0}+\beta_{1} \text { Brothers }_{i}^{h l}+\boldsymbol{X}^{\prime} \boldsymbol{\beta}+\varepsilon_{i}^{h l},
$$

where Education $_{i}^{h l}$ is the highest lifetime education level of individual $i, \operatorname{Brothers}_{i}^{h l}$ is the number of his brothers, and $\varepsilon_{i}^{h l}$ is the regression error. The superscripts $h$ and $l$ stand for household and lineage, respectively. In my analysis I consider a range of other determinants of human capital acquisition, including parental resources, lineage, health, and trends. These factors are captured by the vector $\boldsymbol{X}$ in equation (5), and they will be included successively. ${ }^{60}$

The simple regression of education on the number of brothers gives a negative coefficient of -0.09 (Table 5, column 1). The coefficient says that one brother less is associated with a 0.9 percentage point higher chance of being educated. This compares with a chance of about $7 \%$ that a randomly picked man in my sample would be educated. I will return to a discussion of economic magnitudes below. Inferences are based on standard errors clustered at the level of the household (as defined by the father), which allow for an arbitrary variance-covariance matrix capturing potential correlation in the residual error term (Wooldridge 2007, Ch. 7). In particular, one reason for this clustering is that parent decisions may induce a correlation between the education levels of their sons. It is shown below that other assumptions on the error term, including twodimensional clustering, do not affect these results very much.

\footnotetext{
${ }^{60}$ Brothers is defined as the number of brothers from the same father; results are similar when I include half-brothers and adopted brothers in the analysis.
} 
As a first additional determinant of education outcomes that I consider is birth order (see Black, Devereux, and Salvanes 2005). Including a fixed effect for each birth order level increases the (absolute) size of the coefficient on Brothers (column 2), and I include birth order fixed effects in all remaining specifications. Next I include the birth year of the man, capturing trends in human capital acquisition over time (Trend). The birth year of the man enters the regression with a negative coefficient, which simply picks up that the fraction of men in the sample that are educated declines over time (column 3). Extending this analysis below I allow for more general patterns over time as well as trends that vary across lineages (Table E).

Given that the sample includes lineages with quite different mean levels of human capital (Table C, column 1), and the resources that comes with that, it is reasonable to believe that some men have an easier time to acquire human capital themselves than other men, irrespective of fertility levels. Furthermore, while average human capital levels at the lineage are observed, there could be many unobserved determinants of Education that remain unobserved. To the extent that there are constant over time the inclusion of lineage fixed effects will eliminate their effect, and the Brothers coefficient is identified from changes within the lineage over time. Results are shown in column 4 . There is a substantial increase in the $\mathrm{R}^{2}$, indicating that fixed cross-lineage differences are important. While the coefficient on Brothers remains significant, its size falls upon inclusion of lineage fixed effects. One would have overestimated the importance of fertility differences without accounting for heterogeneity across lineages.

Since the sample has for each man linked information on three generations, I can quantify the role of inter-generational transmission of human capital for educational outcomes in the current generation. Table 5 shows that a man's chance to become educated is increasing in both his father's and his grandfather's human capital levels (column 5). Quantitatively, the size of the coefficients on father's and grandfather's education indicate that past generations' human capital matters a great deal. In particular, the coefficient of about 0.09 on grandfather's education is larger than the chance that a randomly chosen man from the sample is educated (about 7\%). At the same time, having an educated grandfather (and father) put a man into a quite distinct environment in terms of his chance to become educated himself: in the sample, one in three men with educated 
father and grandfather becomes educated himself, whereas a man without educated father and grandfather, this chance is only one in 50 .

In the following I consider a number of other household characteristics that might help to pin down the relationship between the number of brothers and human capital acquisition. In particular, it is possible that a lower number of Brothers is the result of demographic factors that induce couples to have children relatively late, or to have longer periods between their child births (spacing). While such behavior could be motivated by the desire to raise average child quality, there are other possible reasons, such as health or resources factors.

Some light can be shed of these effects for the relationship between fertility and education by considering the parents' age at birth, because older parents will typically have fewer children. We see that while human capital acquisition is less likely for men with relatively old fathers, including father's age at birth if anything strengthens the negative relationship between the number of brothers and education (column 6). The mother's age at birth is not significant (column 7).

Next, I turn to the health of the parents, which is correlated with their longevity, and to the extent that death occurs during the woman's period of fertility it directly affects the number of children she can have. The results indicate that longevity of the father is unrelated to the human capital acquisition of this son (column 8). In contrast, the man's chance to become educated in increasing in the longevity of his mother (column 9). According to these results, the son of a women dying at age 50 has a one percentage point higher chance to become educated compared to a man whose mother dies at age 40. In addition to health, there is evidence that mothers specifically support the education efforts of their sons (see section 2). Overall, including these demographic and health controls strengthens the evidence for a negative relationship between child quantity and child quality (compare the coefficients on Brothers in columns 5 and 10, respectively).

I have also considered the total size of the household, as well as the gender composition of the children. Size is to an extent an indicator of household resources, in particular whether a man comes from a household in which the father had multiple wives. Note that the number of total siblings a man has is not significantly related to his 
education level (column 11). Furthermore, his chances of becoming educated are also unaffected by the share of female children the household has (column 12). In contrast, when the mother's rank in the household was one, a man's chance to become educated is significantly lower (column 13). Mother's rank of one captures primarily a single-woman household, and the negative coefficient reflects that men growing up in households with multiple wives have a better chance of becoming educated due to relatively abundant resources.

Column 13 shows the baseline results in my analysis. We see that controlling for a trend, the inter-generational transmission of human capital, demographic, health, and household size effects, as well as unobserved heterogeneity across lineages, there is a negative relationship between fertility and human capital acquisition. The coefficient on Brothers in column 13 is about -0.09. It means that typically during the early Qing (1644 -1800), one fewer brothers raised the chance of a man to become educated himself by about 0.9 percentage points. Evaluated at the mean of Education, which is 0.067 during this period, this amounts to a $13 \%$ higher chance of becoming educated. Arguably, this is an economically significant magnitude.

One might be concerned that this is only the quantity-quality relationship on average, which might be of limited value if subsets of the Tongcheng population exhibit fertility-human capital patterns that differ strongly from this average. In order to explore this I estimate the baseline specification for a number of subsamples where it is plausible that this effect might be important (see Table 6). In the first subsample, I focus on the men whose father is not educated ( $n=4,239)$. Given the strong inter-generational transmission of human capital documented above, these men would generally be relatively unlikely to acquire human capital themselves. This is reflected in the relatively low average education level of $3.6 \%$, compared to $6.9 \%$ in the baseline sample (see columns 1 and 2, bottom). Also for these men I estimate a significant quantity-quality relationship. The coefficient on Brothers is now lower than before, at $-6.7 \%$ versus $-9.2 \%$. Given the lower average education level for these men with uneducated father, however, lower fertility in form of one brother less is associated with a moderately higher probability of acquiring education when compared to the education mean of the sample (bottom of Table 6, col. 2). 
In a second specification, I focus on the subset of men who have both educated fathers and grandfathers. This is an elite group of $n=349$ men. Although the sample is relatively small and variation is limited, there is evidence that higher fertility is associated with lower human capital levels for these men (column 3). The coefficient on Brothers is about -0.42 , significant at a $10 \%$ level, which is more than four times the size of the coefficient for the whole sample. However, these elite men have roughly a one in three chance to become educated (mean of Education is 0.344 , see bottom of column 3 ). As a consequence, the relatively high coefficient on Brothers means that one brother less for these men is a associated with a higher chance of being educated by about $12 \%$, quite similar to the figure of $13 \%$ that I obtain for the sample as a whole.

This shows that the quantity-quality relationship applies to rather diverse subpopulations in the Tongcheng sample, and furthermore the implied economic magnitude compared to typical education levels of the subpopulations does not drastically differ.

\subsubsection{Robustness}

Probit estimation I begin by showing probit specifications analogous to the earlier results, see Table D. Marginal effects for Brothers are shown at the bottom of the table. The estimates are generally similar to those with OLS in Table 5. In the baseline, the marginal effect of Brothers is -0.098 in the probit, and -0.092 with OLS.

Temporary shocks, trends, and two-way clustering In Table E I examine the importance of temporary shocks and lineage-specific trends for the results, and also explore other assumptions on the error term. Specifically, the baseline specification of column 13 is repeated in the first column. Shown are four sets of alternative standard errors. The first set is clustered by household, as before. ${ }^{61}$ The second set of standard errors is clustered both on household and by decade (16 decades between 1644 and 1800). This accounts for possible correlation of the residual error due to specific shocks in one or several of these decades. The third set of standard errors is two-way clustered by

\footnotetext{
${ }^{61}$ The figures differ because I bootstrap standard errors in Table E for robustness, while standard errors in Table 5 they are analytical; differences are small.
} 
lineage and decade. This accounts for any correlation in the residual errors of men belonging to the same lineage, for example because lineage resources are utilized in the acquisition of human capital of these men. Finally, I present two-way clustered standard errors by household and by lineage-specific cohort. Comparing the different sets of standard errors shows that inferences are not much affected by these different assumptions on the error.

I have also considered a generalized time trend by including fixed effects for each decade in the regression (column 2). This has no major effect on the estimates, indicating that the results are not driven by temporary shocks. Table $\mathrm{E}$ also shows results that include separate trends for each lineage. To the extent that my results are affected by cross-lineage differences in how much the relationship between fertility and human capital changes over time, separate trends for each lineage would pick this up. The results suggest that differential trends across lineages play no role for my results (column 3). Finally, I show results that include indicator variables for men that were born in one of the eleven years in which a new emperor came to power during the period 1644 to 1800 (reign change). Such years can be associated with turmoil and other changes that might affect the relationship between fertility and human capital. The results show that reign change of the emperor does not greatly affect my findings (column 4).

Human capital heterogeneity As described in section 2, during Qing China the levels of human capital attained by men differed as evidenced by whether they had passed a state examination or not, and if they had passed, which level. In the following I examine the quantity-quality relationship separately for those men that prepared but did not pass from those men that passed at least the first level examination. It is reasonable to assume that the latter implied to acquire a higher level of human capital than the former. Results are shown in Table 7.

The baseline quantity-quality relationship is shown in column 1 for comparison. I first focus on men that have prepared for (and hence, acquired human capital) but did not pass the first-level state examination. These $\mathrm{n}=109$ cases are combined with the 4,473 men in the sample that did not invest into human capital (Education $=0)$. I estimate a 
coefficient on Brothers of -0.027 , not significant at standard levels. This is evidence for at best a weak quantity-quality relationship for these men. One interpretation of this is that these households did not reduce fertility enough to be successful in the state examinations. Note also that the coefficients on father's and grandfather's education for these relatively low human capital levels are lower than for higher levels of human capital acquisition.

In contrast, the significant relationship between child quantity and quality reemerges for men with higher human capital investments, those that passed at least the first state examination (column 3). Generally, the regression results for these men are similar to the full sample results given in column 1. Overall, these results indicate that not only was there a negative relationship between child quantity and quality during the early Qing period, it was also stronger for higher human capital investments.

Nearest-neighbor matching One might be concerned that the number of educated people in the sample is small compared to those that are not educated (roughly 6\% versus $94 \%$, respectively), and as a consequence the two groups might differ in ways that are hard to control in a regression. To address this issue, recall that the model describes an equilibrium relationship between child quantity and quality (equation 3), and an alternative approach to the quantity-quality relationship is to ask whether educated men had a lower number of brothers compared to uneducated men.

Given that Education is a 0/1 variable, a matching estimator is natural: each educated man in the sample is paired with the one uneducated man who is as similar as possible in many respects, except education (nearest-neighbor matching). The match is based on the propensity score using all covariates in the baseline regression (Table 5, column 13). This approach has the advantage that the fertility-human capital relationship is examined for relatively similar educated versus uneducated men in the sample. Using this approach, I find that educated men during the early Qing had on average 0.30 fewer brothers than not educated men (Table 7, Panel B, column 1).

For those men that studied for the state examination but did not pass, the difference in the number of brothers to those men that did not acquire human capital is - 
0.17 (column 2). In the third column, it is shown that men making relatively high human capital investments have typically 0.32 fewer brothers.

Overall, this means that the main regression finding of a negative child quantitychild quality relationship is not driven by differences in characteristics between educated and non-educated men that regression covariates cannot control for. The matching approach yields two additional results. First, the focus on a more narrowly defined comparison shows that even for relatively low levels of human capital there is a marginally significant (10\% level) negative relationship between child quantity and quality. Second, the nearest-neighbor matching results show that the negative relationship is strongest for relatively high human capital investments, which was not the case using the regression approach (see columns 3 and 1 in Panels A and B).

Differences across lineages There is a substantial amount of variation in terms of human capital accumulation across lineages (Table $\mathrm{C}$ ). To examine whether the negative child quantity-quality relationship found above is robust, I re-estimate the baseline specification (Table 5, column 13) with one of the lineages dropped at a time. The analysis shows that none of the lineages by itself drives the estimated quantity-quality relationship (see Table F). While certain lineages play a role for some of the results, such as the coefficient on grandfather's education, which is lower without the $M a$ and higher without the Wang lineage, overall the results are quite stable. In particular, the coefficient on Brothers is negative in all specifications, varying in a relatively narrow range around the full-sample estimate of about -0.09 .

I now turn to the role of non-human capital investments.

Purchased degrees The focus on the human capital-fertility relationship means that in the main analysis I abstract from those men who obtain degree and official position through purchase as opposed to passing the state examination. It is possible though that the purchase of a degree had implications for fertility that were not unlike those when the degree was obtained through human capital acquisition. The following analysis explores this (see Table G). 
Coding the purchased degrees as Education equal to one instead of zero, I find that the negative relationship between quantity and quality remains (column 2 ). In the next specification I include the interaction Brothers x Purchase, where Purchase is one if the degree is purchased and zero otherwise. The coefficient on this interaction is positive at about 2 . This means that the quantity-quality relationship is weaker for non-human capital investments than for human capital investments. Is there evidence for a negative relationship at all? The answer is yes. While one brother less is associated with a 0.9 percentage points higher chance of becoming educated, one brother less means a 0.6 percentage points higher chance that a degree is purchased. I have also examined whether there is evidence that the role of father's and grandfather's education depends on whether the degree is purchased or not, finding no evidence for it (column 4).

\subsubsection{The impact of a higher return on human capital accumulation: results from an instrumental-variables approach}

While I have shown in sections 5.2.1 and 5.2.2 that the negative child quantityquality relationship is not explained by a range of omitted variables, it remains possible that this is influenced by specific households that decided to educate a son once the return to human capital had increased by the $17^{\text {th }}$ century.

In order to obtain exogenous variation I exploit the fact that the early birth of a daughter tends to reduce a household's number of sons while at the same time a daughter would not matter for human capital acquisition decision because women were precluded from participating in the state examinations. Early-born daughters reduce the number of sons because it generally leaves less time for the household to have more sons. This is necessarily the case for a given couple given the woman's fertile period is limited, however it also applies for multiple-wives households given the increasing age of the father.

Because the Tongcheng genealogies give only gender-specific, not overall birth order, I cannot employ birth order as an instrumental variable for the entire sample. For 
the subset of observations with fathers that had several wives consecutively, I can use information on the number of daughters from each wife to construct a gender-based birthorder measure. Specifically, if a man has a high number of half-sisters from his father's earlier marriages (denoted by Earlier_halfsis), the man should have relatively few brothers. In the subsample of households with multiple wives in the parent generation, a simple regression of Brothers on Earlier_halfsis yields a coefficient of -0.017 (s.e. 0.009; $\mathrm{n}=338)$.

Based on this I adopt a two-stage least squares approach with the second stage given by equation (7)

$$
\text { Education }_{i}^{h l}=\beta_{0}+\beta_{1} \text { Brothers }_{i}^{h l}+\boldsymbol{X}^{\prime} \boldsymbol{\beta}+\varepsilon_{i}^{h l},
$$

where in the first-stage regression the variable Brothers is instrumented by the number of earlier half sisters, Earlier_halfsis

$$
\text { Brothers }_{i}^{h l}=\delta_{0}+\sum_{v} \delta_{1 v} \text { Earlier_halfsis }_{i}^{h l}+\boldsymbol{X}^{\prime} \boldsymbol{\delta}+u_{i}^{h l} .
$$

The subscript $v, v=1, \ldots, 5$ is an indicator for the number of the wife in the household, which means that the impact of earlier half sisters on Brothers is allowed to vary, for example, between the second and the third wife. Results are shown in Table 8, column 3 .

The first-stage regression (8) yields an Angrist-Pischke F-statistic of about 25, suggesting that the instruments have some power despite the relatively small sample ( $\mathrm{n}=$ 335). The second-stage coefficient on Brothers is estimated at about -2, marginally significant at a $10 \%$ level. The result suggests that lowering fertility leads to higher human capital accumulation. In terms of magnitude, the instrumental-variables effect of fertility on education is quite large (compare with the OLS results for the sample as a whole, and the multiple-wives sample in columns 1 and 2, respectively); the relatively small number of observations could play a role in this. While the reader should be 
cautious about placing too much emphasis on this instrumental variables estimation, finding some evidence for a causal effect from fertility reductions on increases in human capital accumulation strengthens the evidence on a negative relationship between child quantity and quality provided so far.

Having established that the early Qing was characterized by a negative relationship between education and fertility, I now turn to examining whether this changed as the returns to human capital fell in the subsequent period.

\subsection{The fading of the quantity-quality relationship towards the end of the Qing}

In this section I examine the evidence for a change in the quantity-quality relationship over time. As discussed in section 2, there is evidence that the return to human capital fell over the Qing era, with men working as teachers earning much less towards the end of the Qing than in earlier times, for example. According to the model presented in section 3, this should lead to a weakening in the relationship between fertility and education. To be sure, China witnessed many other changes over the Qing period, including the opening of foreign treaty ports in the nineteenth century, natural disasters, rebel activity, and the eventual end of China's imperial period. ${ }^{65}$ Because this poses challenges for tracing the quantity-quality relationship over relatively short periods of time, I adopt a broader approach in which only two subperiods are compared, the Early and the Late Qing era. My baseline for the split between early and late Qing is the year $1800 .{ }^{66}$ Below the robustness of the findings with respect to this breakdown into two periods is discussed.

The coefficient on Brothers for the Early Qing period of 1644-1800 is the baseline result of -0.092 (Table 5, column 13), which is reproduced in Table 9, column 1. For the Late Qing period, I estimate a coefficient on Brothers of virtually zero (Table 9, column 2). Figure 3 illustrates the stark difference in the quantity-quality relationship

\footnotetext{
65 The closest treaty port to Tongcheng was Wuhu, located in Anhui province.

${ }^{66}$ The change from the $18^{\text {th }}$ to the $19^{\text {th }}$ century appears to be a natural choice; the year 1800 is also not long after the end of the reign of the Qianlong emperor (1796), which is often considered as a period of relatively high levels of development.
} 
between the early and late Qing periods. ${ }^{67}$ In the early period, lower fertility was associated with higher human capital acquisition, while this is no longer the case in the Late Qing period. The result is even more remarkable given that several other determinants of human capital acquisition, such as father's education and grandfather's education, change very little from the early to the late Qing.

To what extent does this result depend on using the year 1800 to separate the early from the late Qing period? This is explored this by shifting the breakpoint between the periods to other breakpoints ranging from 1780 to 1820 . These results for shifting the breakpoint by five years at a time are shown as well in Table 9. The key findings are that independent of the specific year to separate early from late Qing period there is, first, always a significant quantity-quality relationship for the Early Qing, and second, there is never a significant quantity-quality relationship for the Late Qing.

The result is confirmed using probit regressions, as shown in Table H. In Figure 4 I show the probit marginal effects on Brothers for alternative dates for separating early from late Qing periods. In the baseline with periods (1644-1800) and (1800-), the Brothers marginal effect estimate is -0.098 for the Early and 0.016 for the Late Qing (shown in the center of Figure 4). For alternative breakpoints into early and late Qing, the quantity-quality relationship during the early period is there while for the Late Qing it is not.

One might still be concerned that the result of a stark change in the quantityquality relationship from the early to the late Qing period is in part driven by the regression approach in which a declining number of educated men are compared to a large and increasing number of uneducated men. To address this concern I have employed the nearest-neighbor matching approach from above to compare the number of brothers that educated and not educated men had during the Early versus the Late Qing. These results, summarized in Figure A, confirm the regression results of Tables 9 and $\mathrm{H}$. Specifically, for any particular year dividing the Qing into early and late subperiods between 1780 and 1820, during the Early Qing uneducated men had always a

\footnotetext{
${ }^{67}$ I take as Late Qing observations all men with birth year of 1800 or later; this includes a few that were born after the fall of the Qing in 1911; they do not drive the result.
} 
significantly higher number of brothers than educated men. In contrast, during the Late Qing uneducated men had never a significantly higher number of brothers than educated men. This confirms that the result that the quantity-quality relationship disappeared during the later Qing period is not driven by the inability of the regression approach to yield informative treatment-and-control comparisons.

\section{Robustness}

It could be that my results for the Late Qing period are affected by temporary shocks, foreign intrusion, as well as internal warfare. To assess the influence of these events on my results I re-estimate the fertility-education relationship with decade-specific fixed effects (Table I). Comparing column 2 with column 1, there is no evidence that the results on quantity-quality during the Late Qing are strongly affected by such shocks.

I also revisit the question of non-human capital investments to obtain official positions in the form of purchased degrees. Because of low tax revenue during the Taiping Rebellion, the government resorted to the sale of government office during the mid- $19^{\text {th }}$ century. Here I ask how this affects my estimate of the fertility-education relationship during the Late Qing. I begin with a specification where the Education variable is recoded from zero to equal one in the case of a degree purchase, which yields a negative but insignificant coefficient on Brothers (column 3, Table I). I also allow for an interaction variable between Brothers and Purchased Degree. This interaction enters positively, indicating that there is more evidence for a child quantity-quality trade-off for human capital investments than for degree purchases. This confirms the result for the Early Qing era above. With about 1.5\% of the Late Qing sample having a purchased degree, the marginal effect of Brothers in the case of degree purchase is about -0.01 , compared to about -0.04 in the case of human capital investments (no degree purchase). In either case the coefficients are not significantly different from zero, thus accounting for the extent of degree sales of the Qing government during the $19^{\text {th }}$ century does not change the main finding.

As a final step in my robustness analysis for the Late Qing, I have estimated the effect of fertility on education using the instrumental-variables approach that was employed earlier (section 5.2.2). In contrast to the Early Qing, during the Late Qing I do 
not estimate a positive effect from lower fertility on education; see Table 8, columns 3 and 4. Furthermore, there is little evidence that this difference in the results is due to a weakening of the instrumental variable (Earlier_halfsis), because although weaker the first-stage F-statistic is still sizable.

Overall, I find a robust quantity-quality relationship for the relatively early years of the Qing. This is consistent with the hypothesis that the state examinations provided households a clear path to upward mobility through human capital accumulation, which in turn was facilitated by a relatively low number of children. Towards the end of the Qing, this quantity-quality relationship disappeared. This is consistent with the lower return to education shifting the household choice away from quality (education) and towards quantity (fertility).

\section{Conclusions}

Since the process of industrialization involves dramatic increases in the return to human capital, an important issue in long-run development relates to the origins of fertility behavior as the incentives to human capital accumulation change. This paper shows that in China, there is evidence of fertility control for human capital objectives starting in the $17^{\text {th }}$ century. Here I have shown that the changes promoted by the Qing state in the legitimacy of the civil service examination as an exclusive and predictable channel in which to pursue high status official careers increased the return to education and a negative quantity-quality relationship emerged. We have also seen that the decline in the return to education towards the end of the Qing led to the disappearance of the negative quantity-quality relationship. Together this is evidence that economic incentives affect the quantity-quality choice.

This presents new evidence that child quantity-quality tradeoffs are not necessarily the exclusive consequence of industrialization, which would not arrive in China for another several centuries. The findings also show that over the late Qing, the quantity-quality relationship disappeared over time. The reduced intensity of the quantity-quality tradeoff in China during the latter half of the Qing dynasty also shows 
that fertility control behavior can rise and fall, reversing the course that it had been set on previously. China's lagging performance relative to Europe in the $18^{\text {th }}$ and $19^{\text {th }}$ centuries has triggered influential work on the sources of divergence (Pomeranz 2000; Broadberry and Gupta 2006). The finding of this paper, which shows declining rewards to human capital in China in the $18^{\text {th }}$ and $19^{\text {th }}$ centuries, is generally consistent with the pattern of divergence and per capita standards of living falling further behind that of Britain, Western Europe, and other industrializing nations.

Whereas the history of Western countries to date appear to show a broad trend of increasing industrialization and lower fertility, it is possible that future micro studies will reveal more intricate patterns, as well reversals, at least within certain subsamples observed at the individual level. More generally, additional research on how differences in rewards to education affected fertility choices of different groups of people in the past should aid our understanding of the process of economic development. 


\section{References}

Basso, Alberto (2012) "Fertility transition and the quantity-quality trade-off: historical evidence from Spain.” Mimeo.

Beattie, Hillary (1979), Land and Lineage in China: A Study of T'ung-ch'eng County, Anhwei, in the Ming and Ch'ing Dynasties. New York: Cambridge University Press.

Becker, Gary S. (1960), "An Economic Analysis of Fertility," in Ansley J. Coale, ed., Demographic and economic change in developed countries. Princeton: Princeton University Press.

Becker, Sascha O., Francesco Cinnirella, and Ludger Woessmann (2012), "The Effect of Investment in Children's Education on Fertility in 1816 Prussia”, Cliometrica 6(1): 29-44.

Becker, Sascha O., Francesco Cinnirella, and Ludger Woessmann (2010), "The trade-off between fertility and education: evidence from before the demographic transition." Journal of Economic Growth, 15(3): 177-204.

Becker, Sascha O., and Ludger Woessmann (2009), "Was Weber Wrong? A Human Capital Theory of Protestant Economic History", Quarterly Journal of Economics 124(2): 531-596.

Black, Sandra E. Paul J. Devereaux and Kjell G. Salvanes (2005), “The More the Merrier? The Effect of Family Size and Birth Order on Children's Education." The Quarterly Journal of Economics, 120 (2): 669-700.

Broadberry, Stephen and Bishnupriya Gupta (2006), “The Early Modern Great Divergence: Wages, Prices, and Economic Development in Europe and Asia, 1500-1800." Economic History Review, 59(1)’2-31.

Campbell, Cameron D., Wang Feng, and James Z. Lee (2002), "Pretransitional Fertility in China", Population and Development Review 28(4): 735-750.

Chang, Chung-li (1955), The Chinese Gentry: Studies on their Role in Nineteenth Century Chinese Society. Seattle: University of Washington Press.

Chang, Chung-li (1962), The Income of the Chinese Gentry. Seattle: University of Washington Press.

Clark, Gregory (2007), A Farewell to Alms, Princeton University Press.

Coale, Ansley J. (1985), "Fertility in Rural China: A Reconfirmation of the Barclay Reassessment." In S. Hanley and A.P. Wolf, eds., Family and Population in East Asian History, Stanford: Stanford University Press. 
Collins, William, and Marianne Wannamaker (2015), "Up from Slavery”, paper presented at University of Colorado, Boulder.

Cong, Xiaoping (2007), Teachers' Schools and the Makign of the Modern Chinese Nation-State, 1897-1937, UBC Press.

Crafts, Nicholas (1995), "Exogenous or Endogenous Growth? The Industrial Revolution Reconsidered." Journal of Economic History 55(4): 745-72.

DeLong, J. Bradford, Claudia Goldin and Lawrence F. Katz (2003), "Sustaining U.S. Economic Growth." In Agenda for the Nation, edited by Henry Aaron, James M. Lindsay, and Pietro S. Niyola, 17-60. Washington, D.C.: Brookings Institution Press, 2003.

Dittmar, Jeremiah (2011), "Information Technology and Technological Change: The Impact of the Printing Press", Quarterly Journal of Economics 126 (3): 1133-1172.

Doepke, Matthias, 2004. "Accounting for Fertility Decline During the Transition to Growth." Journal of Economic Growth 9(3): 347-383.

Durand, John D. (1977), "Historical Estimates of World Population: An Evaluation." Population and Development Review 3(3): 253-296.

Daqinghuidian shili (1899 edition) Ch. 370. (ref p.9 fn. 16)

Easterlin, Richard A. and E.M. Crimmins (1985), The Fertility Revolution: A SupplyDemand Analysis. University of Chicago Press.

Ebrey, Patricia, B. (1993), Chinese Civilization: A Sourcebook, $2^{\text {nd }}$ ed. Free Press.

Elliot, Mark (2001). The Manchu Way: The Eight Banners and Ethnic Identity in Late Imperial China. Stanford.

Elman, Benjamin (1991), "Political, Social, and Cultural Reproduction via Civil Service Examinations in Late Imperial China”, Journal of Asian Studies 50(1): 7-28.

Elman, Benjamin (1994), "Changes in Civil Service Examinations from the Ming to the Ch'ing Dynasties," in Benjamin Elman and Alexander Woodside, eds., Education and Society in Late Imperial China, 1600-1900. Berkeley: University of California Press.

Elman, Benjamin (2000), A Cultural History of Civil Examinations in Late Imperial China. Los Angeles: University of California Press.

Elman, Benjamin (2002), "The Social Roles of Literati in Early to Mid-Ch'ing." Part one: The Ch'ing Empire to 1800. Ed. Willard J. Peterson. Cambridge University Press. 
Fei, John C. H. , and Ts'ui-jung Liu (1982), "The Growth and Decline of China Family Clans", Journal of Interdisciplinary History XII:3 (Winter): 375-408.

Fernihough, Alan, 2011. "Human Capital and the Quantity-Quality Trade-Off during the Demographic Transition: New Evidence from Ireland," Working Papers 201113, School of Economics, University College Dublin.

Galor, Oded, 2011. Unified Growth Theory. Princeton: Princeton University Press.

Galor, Oded. 2012. "The Demographic Transition: Causes and Consequences." Cliometrica 5(1): 1-28.

Galor, Oded and Omer Moav, 2002. "Natural Selection and the Origin of Economic Growth." Quarterly Journal of Economics 115: 469-498.

Galor, Oded and David Weil, 2000. "Population, Technology and Growth: From Malthusian Stagnation to the Demographic Transition and Beyond." American Economic Review 90: 806-828.

Garrett, Eilidh, Alice Read, Kevin Schurer, and Simon Szreter, 2001. Changing Family Size in England and Wales: Place, Class and Demography, 1891-1911. Cambridge, U.K.: Cambridge University Press.

Greenhalgh, Susan, 1988. "Fertility as Mobility: Sinic Transitions." Population and Development Review 14(4): 629-674.

Guinnane, Timothy, 2011. "The Historical Fertility Transition: A Guide for Economists." Journal of Economic Literature 49(3): 589-614.

Haines, Michael R. and J. David Hacker, 2011. "Spatial Aspects of the American Fertility Transition in the Nineteenth Century," In Myron Gutmann, Kenneth M. Sylvester, and Glenn D. Deane, eds., Space and Time in Historical Demographic Studies: New Methods and Models. Springer, pp. 37-63.

Harrell, Stevan, 1985. "The Rich Get Children: Segmentation, Stratification, and Population in Three Chekiang Lineages, 1550-1850." In S. Hanley and A.P. Wolf, eds., Family and Population in East Asian History, Stanford: Stanford University Press.

Harrell, Stevan, 1987. “On the Holes in Chinese Genealogies.” Late Imperial China 8(2): 53-77.

Ho, Ping-ti (1959), Studies on the Population of China, 1368-1953. Cambridge: Harvard University Press.

Ho, Ping-ti (1962), The Ladder of Success in Imperial China: Aspects of Social Mobility (1368-1911). New York: Columbia University Press. 
Klemp, Marc and Jacob Weisdorf (2012), "Fecundity, Fertility and Family Reconstitution Data: The Child Quantity-Quality Trade-Off Revisited.” Working paper.

Knodel, John (1988), Demographic Behavior in the Past: A Study of Fourteen German Villages in the Eighteenth and Nineteenth Centuries. New York: Cambridge University Press.

Lavely, William (2007), "Sex, Breastfeeding, and Marital Fertility in Pre-transition China." Population and Development Review 33(2): 289-320.

Lavely, William and R. Bin Wong (1998), "Revising the Malthusian Narrative: The Comparative Study of Population Dynamics in Late Imperial China." The Journal of Asian Studies, Vol. 57, No. 3. (Aug.), pp. 714-748.

Lavely, William, James Lee, and Feng Wang (1990), "Chinese demography: the state of the field." The Journal of Asian Studies 49(4): 807-834.

Lee, Ronald (2003), “The Demographic Transition: Three Centuries of Fundamental Change," Journal of Economic Perspectives, 17(4) pp. 167-190.

Lee, James and Cameron Campbell (1997), Fate and Fortune in Rural China: Social organization and Population behavior in Liaoning 1774-1873. New York: Cambridge University Press.

Lee, James and Cameron Campbell, and Lawrence Anthony (1995), "A Century of Mortality in Rural Liaoning, 1774-1873”. In Harrell, Stevan, ed. 1995. Chinese Historical Microdemography. Berkeley: University of California Press.

Lee, James and Feng Wang (2001), One Quarter of Humanity, Malthusian Mythology and Chinese Realities, 1700-2000. Cambridge: Harvard University Press.

Leung, Angela Ki Che (1994), "Elementary Education in the Lower Yangtze Region in the Seventeenth and Eighteenth Centuries," in Alexander Woodside and Benjamin A. Elman eds., Education and Society in Late Imperial China. Berkeley: University of California Press.

Liu Ts'ui-jung (1978), "Chinese genealogies as a source for the study of historical demography." In Studies and essays in commemoration of the golden jubilee of Academia Sinica. Taipei: Academia Sinica.

Liu, Ts'ui-jung (1980), “The Demographic Dynamics of Some Clans in the Lower Yangtze Area, c. 1400-1900", paper presented at the International Conference on Sinology, Taipei. 
Long, Jason, and Joseph Ferrie (2013), "Intergenerational Occupational Mobility in Great Britain and the United States since 1850." American Economic Review, 103(4): 1109-37.

McEvedy, Colin and Richard Jones (1978), Atlas of world population history. Harmondsworth, Middlesex: Penguin Books Ltd.

Miyazaki, Ichisada (1981), China's Examination Hell: The civil service examinations of imperial China, trans. Conrad Schirokauer. New York: Weatherhill.

Moav, Omer (2005), "Cheap Children and the Persistence of Poverty", Economic Journal 115: $88-110$.

Mokyr, Joel (2012), The Enlightened Economy: An Economic History of Britain 17001850. New Haven: Yale University Press.

Murphy, Tommy, E. (2015), "Old habits die hard (sometimes).” Journal of Economic Growth 20(2): 177-222.

Perkins, Dwight H., 1969. Agricultural Development in China, 1368-1968. Chicago, IL: Aldine.

Pomeranz, Kenneth (2000), The Great Divergence: China, Europe, and the Making of the Modern World Economy." Princeton University Press.

Rawski, Evelyn S. (1979), Education and Popular Literacy in Ch'ing China. Ann Arbor: University of Michigan Press.

Shiue, Carol H. (2015), "Economic Status and Intergenerational Mobility in Chinese Clans." Mimeo.

Shiue, Carol H. and Wolfgang Keller (2007), "Markets in China and Europe on the Eve of the Industrial Revolution.” American Economic Review 97(4): 1189-1216.

Shryock, Henry S. and Jacob S. Siegel (1973), The Methods and Materials of Demography. New York: Academic Press.

Telford, Ted A. (1995), "Fertility and Population Growth in the Lineages of Tongcheng County, 1520-1661.” Chinese Historical Microdemography, ed. S. Harrell. Berkeley: University of California Press.

Telford, Ted A. (1990), "Patching the holes in Chinese genealogies." Late Imperial China. 11(2): 116- 35.

Telford, Ted A. (1986), "A survey of social demographic data in Chinese genealogies." Late Imperial China 7: 118-48. 
Twitchett, Denis and Frederick W. Mote (1998), The Cambridge History of China (eds.), Vol. 8. New York: Cambridge University Press.

Wakeman, Fredrick E. (1975), The Fall of Imperial China. New York: The Free Press.

Wang, Yeh-chien, (1974), Land taxation in Imperial China, 1750-1911. Cambridge, MA: Harvard University Press.

Wolf, Arthur P. (2001), "Is There Evidence of Birth Control in Late Imperial China?" Population and Development Review 27:133-154.

Wooldridge, Jeffrey M. (2007), Econometric analysis of cross section and panel data, MIT Press.

World Bank (2014), Annual Report Overview, 2014. http://www.worldbank.org/en/ about/annual-report/overview\#HumanDevelopment

Yuchtman, Noam (2014), "Teaching to the Tests: An Economic Analysis of Traditional and Modern Education in Late Imperial and Republican China", working paper, UC Berkeley Haas, December.

Zhao, Zhongwei (2002), "Fertility Control in China's Past", Population and Development Review 28(4): 751-757.

Zhao, Zhongwei (2001), "Chinese genealogies as a source for demographic research: A further assessment of their reliability and biases", Population Studies 55: 181-193.

Zhao, Zhongwei (1994), "Demographic Conditions and Multi-generation Households in Chinese History. Results from Genealogical Research and Microsimulation", Population Studies 48: 413-425. 


\section{Table 1. Education and socioeconomic status}

\begin{tabular}{|c|c|c|c|c|}
\hline Education & Status & Obs. & Percent & Description \\
\hline 0 & 0 & 6,956 & 71.08 & No titles, degrees, office, other evidence of wealth \\
\hline 0 & 1 & 36 & 0.37 & Honorary or posthumous titles; main guest at the county banquet; village head \\
\hline 0 & 2 & 786 & 8.03 & Multiple wives in consecutive marriage, two or more not living at the same time \\
\hline 0 & 3 & 912 & 9.32 & Father a sheng-yuan, minor official, or official student; evidence of wealth, jian-sheng, expectant off \\
\hline 0 & 4 & 23 & 0.24 & Grandfather a juren, gongsheng,jinshi, or official \\
\hline 0 & 5 & 38 & 0.39 & Father a juren, gongsheng, jinshi, or official \\
\hline 0 & 7 & 89 & 0.91 & Concubinage (i.e. polygyny, two or more wives or concubines at the same time) \\
\hline 0 & 8 & 11 & 0.11 & $\begin{array}{l}\text { Substantial evidence of wealth and property; set up ancestral estates, large donations, philanthrop } \\
\text { wealthy farmer, landowner, or merchant }\end{array}$ \\
\hline 0 & 10 & 1 & 0.01 & Military sheng-yuan, minor military office \\
\hline 0 & 11 & 146 & 1.49 & Purchased jian-sheng and/or purchased office \\
\hline 0 & 14 & 102 & 1.04 & Expectant official, no degrees \\
\hline 0 & 17 & 45 & 0.46 & Civil official with no degree, minor degree, or purchased degree \\
\hline 1 & 6 & 163 & 1.67 & $\begin{array}{l}\text { Educated, scholar, no degrees or office; editor of genealogy, refused office, or prepared for but did: } \\
\text { pass exam }\end{array}$ \\
\hline 1 & 9 & 193 & 1.97 & Official students \\
\hline 1 & 12 & 99 & 1.01 & Students of the Imperial Academy (non-purchased) \\
\hline 1 & 13 & 53 & 0.54 & Civil sheng-yuan; minor civil office \\
\hline 1 & 15 & 4 & 0.04 & Expectant official with one of the lower degrees \\
\hline 1 & 16 & 28 & 0.29 & Military juren, jinshi; major military officer \\
\hline 1 & 18 & 27 & 0.28 & Juren, gongsheng, with no office \\
\hline 1 & 19 & 56 & 0.57 & Juren, gongsheng, with expectant office \\
\hline 1 & 20 & 0 & 0.00 & Jinshi, no office \\
\hline 1 & 21 & 11 & 0.11 & Jinshi with official provincial post or expecant official \\
\hline 1 & 22 & 7 & 0.07 & $\begin{array}{l}\text { Jinshi with top-level position in Imperial bureaucracy (Hanlin Academy, Grand Secretariat, Five } \\
\text { Boards, Prime Minister, etc.) }\end{array}$ \\
\hline
\end{tabular}

Notes: Table gives education and status for 9,787 of the adult men in the sample; coding developed using Chang (1959), Ho (1962), and Telford (1986 See text for descriptions of the degree titles. 
Table 2. Sample summary statistics

\begin{tabular}{|c|c|c|c|c|c|c|c|c|c|c|c|c|}
\hline \multirow[t]{2}{*}{ Variable } & \multicolumn{3}{|c|}{ Full sample } & \multicolumn{3}{|c|}{$\begin{array}{c}\text { Yuan and Ming Dynasties } \\
\text { (Before 1644) }\end{array}$} & \multicolumn{3}{|c|}{$\begin{array}{c}\text { Early Qing } \\
(1644-1800)\end{array}$} & \multicolumn{3}{|c|}{$\begin{array}{c}\text { Late Qing } \\
\text { (1800 and later) }\end{array}$} \\
\hline & Obs. & Mean & Std. & Obs. & Mean & Std. & Obs. & Mean & Std. & Obs. & Mean & Std. \\
\hline Education & 8,893 & 0.063 & 0.244 & 601 & 0.165 & 0.371 & 4,951 & 0.067 & 0.251 & 3,341 & 0.039 & 0.194 \\
\hline Birth order & 8,892 & 1.976 & 1.423 & 601 & 1.684 & 1.352 & 4,950 & 1.940 & 1.390 & 3,341 & 2.083 & 1.473 \\
\hline No. of brothers & 8,893 & 3.284 & 1.620 & 601 & 2.777 & 1.511 & 4,951 & 3.264 & 1.576 & 3,341 & 3.404 & 1.683 \\
\hline Birth year & 8,893 & 1.764 & 0.071 & 601 & 1.580 & 0.053 & 4,951 & 1.744 & 0.039 & 3,341 & 1.826 & 0.016 \\
\hline Father education & 8,893 & 0.106 & 0.308 & 601 & 0.233 & 0.423 & 4,951 & 0.116 & 0.320 & 3,341 & 0.069 & 0.253 \\
\hline Grandfather education & 8,893 & 0.152 & 0.359 & 601 & 0.213 & 0.410 & 4,951 & 0.165 & 0.371 & 3,341 & 0.120 & 0.325 \\
\hline Father's age at birth & 8,893 & 31.868 & 8.439 & 601 & 29.047 & 7.479 & 4,951 & 31.538 & 8.534 & 3,341 & 32.865 & 8.307 \\
\hline Mother's age at birth & 8,893 & 28.267 & 6.843 & 601 & 25.983 & 6.186 & 4,951 & 28.313 & 6.940 & 3,341 & 28.611 & 6.733 \\
\hline Father's age at death & 8,658 & 57.442 & 12.942 & 596 & 55.284 & 11.766 & 4,939 & 58.578 & 13.501 & 3,123 & 56.057 & 12.039 \\
\hline Mother's age at death & 8,252 & 58.379 & 14.657 & 595 & 54.353 & 13.431 & 4,807 & 59.892 & 14.812 & 2,850 & 56.667 & 14.291 \\
\hline Total no. of siblings & 8,892 & 4.845 & 2.208 & 601 & 3.681 & 1.997 & 4,950 & 4.742 & 2.063 & 3,341 & 5.209 & 2.360 \\
\hline Share of siblings female & 8,891 & 0.267 & 0.208 & 601 & 0.163 & 0.206 & 4,949 & 0.264 & 0.208 & 3,341 & 0.291 & 0.202 \\
\hline Mother's rank is one & 8,893 & 0.902 & 0.298 & 601 & 0.913 & 0.281 & 4,951 & 0.925 & 0.263 & 3,341 & 0.865 & 0.342 \\
\hline
\end{tabular}

Notes: Birth year is defined as man's birth year divided by 1,000 . 
Table 3. Sample characteristics of educated vs non-educated men

\begin{tabular}{|c|c|c|c|c|c|c|c|c|c|c|}
\hline & $\begin{array}{l}\text { Birth } \\
\text { year }\end{array}$ & $\begin{array}{l}\text { Birth } \\
\text { month }\end{array}$ & $\begin{array}{c}\text { Number } \\
\text { of } \\
\text { wives }\end{array}$ & $\begin{array}{l}\text { Age at } \\
\text { death }\end{array}$ & $\begin{array}{r}\text { Father's } \\
\text { education }\end{array}$ & $\begin{array}{c}\text { Number } \\
\text { of } \\
\text { brothers }\end{array}$ & $\begin{array}{l}\text { Number } \\
\text { of } \\
\text { siblings }\end{array}$ & $\begin{array}{l}\text { Share } \\
\text { female } \\
\text { siblings }\end{array}$ & $\begin{array}{l}\text { Wife age } \\
\text { at death }\end{array}$ & $\begin{array}{c}\text { Wife's } \\
\text { father } \\
\text { educated }\end{array}$ \\
\hline \multicolumn{11}{|c|}{ No Education } \\
\hline Mean & 1766.33 & 6.90 & 1.16 & 49.53 & 0.08 & 3.30 & 4.83 & 0.26 & 46.78 & 0.05 \\
\hline Std. & 0.77 & 0.04 & 0.005 & 0.19 & 0.003 & 0.02 & 0.02 & 0.002 & 0.23 & 0.003 \\
\hline Obs. & 8,329 & 8,329 & 8,329 & 6,798 & 8,329 & 8,329 & 8,328 & 8,327 & 6,349 & 4,780 \\
\hline \multicolumn{11}{|c|}{ Educated } \\
\hline Mean & 1727.98 & 6.90 & 1.47 & 54.71 & 0.54 & 3.09 & 5.02 & 0.30 & 54.57 & 0.30 \\
\hline Std. & 3.43 & 0.14 & 0.031 & 0.70 & 0.003 & 0.06 & 0.10 & 0.009 & 0.77 & 0.02 \\
\hline Obs. & 564 & 564 & 563 & 520 & 564 & 564 & 564 & 564 & 520 & 466 \\
\hline \multicolumn{11}{|c|}{ Difference } \\
\hline Mean & $38.35^{* *}$ & -0.002 & $-0.31^{* *}$ & $-5.18^{* *}$ & $-0.46^{* *}$ & $0.20^{* *}$ & $-0.19 *$ & $-0.03^{* *}$ & $-7.79 * *$ & $-0.24^{* *}$ \\
\hline \multicolumn{11}{|l|}{ Total } \\
\hline Mean & 1763.9 & 6.90 & 1.18 & 49.90 & 0.11 & 3.28 & 4.84 & 0.27 & 47.37 & 0.07 \\
\hline Std. & 3.08 & 0.04 & 0.005 & 0.18 & 0.004 & 0.02 & 0.02 & 0.002 & 0.22 & 0.004 \\
\hline Obs. & 8,893 & 8,893 & 8,892 & 7,318 & 8,893 & 8,893 & 8,892 & 8,891 & 6,869 & 5,246 \\
\hline
\end{tabular}

Notes: ${ }^{* *} /{ }^{*}$ significant at a $1 \% / 5 \%$ level. 
Table 4. Education and fertility: Yuan-Ming vs. Qing

\begin{tabular}{lcccc} 
& \multicolumn{2}{c}{$(1)$} & $(3)$ & \\
\cline { 2 - 3 } & \multicolumn{2}{c}{ Education } & & \\
\cline { 1 - 2 } Yuan-Ming & $\begin{array}{c}3.131 \\
(\mathrm{n}=99)\end{array}$ & $\begin{array}{c}2.707 \\
(\mathrm{n}=502)\end{array}$ & 0.424 & 0.995 \\
Qing & $\begin{array}{c}3.087 \\
(\mathrm{n}=465)\end{array}$ & $\begin{array}{c}3.334 \\
(\mathrm{n}=7827)\end{array}$ & -0.247 & 0.007 \\
& & & \\
Early Qing & 2.934 & 3.288 & -0.351 & 0.000 \\
(1644-1800) & $(\mathrm{n}=334)$ & $(\mathrm{n}=4617)$ & &
\end{tabular}

Notes: Columns 1 and 2 report the mean number of brothers by man's education status between the different eras. 
Table 5. The quantity-quality relationship during the early Qing (1644-1800)

\begin{tabular}{|c|c|c|c|c|c|c|c|c|c|c|c|c|c|}
\hline \multirow{2}{*}{ 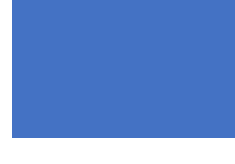 } & \multirow{2}{*}{ (1) } & \multirow{2}{*}{$\begin{array}{l}\text { (2) } \\
\text { Birth } \\
\text { order }\end{array}$} & \multirow{2}{*}{$\begin{array}{c}\text { (3) } \\
\text { Trend }\end{array}$} & \multirow{2}{*}{$\begin{array}{c}\text { (4) } \\
\text { Lineage } \\
\text { FE }\end{array}$} & \multirow{2}{*}{$\begin{array}{c}\text { (5) } \\
\text { Lineal } \\
\text { HC }\end{array}$} & \multirow{2}{*}{\multicolumn{2}{|c|}{$\begin{array}{l}\text { (6) } \\
\text { Early start and } \\
\text { spacing }\end{array}$}} & (8) & (9) & \multirow[t]{2}{*}{ (10) } & (11) & (12) & \multirow{2}{*}{$\begin{array}{c}\text { (13) } \\
\text { Rank } \\
\text { motheI }\end{array}$} \\
\hline & & & & & & & & Lor & vity & & & & \\
\hline Brothers & $\begin{array}{c}-0.090^{* *} \\
(0.026)\end{array}$ & $\begin{array}{c}-0.140^{* *} \\
(0.034)\end{array}$ & $\begin{array}{c}-0.134^{* *} \\
(0.033)\end{array}$ & $\begin{array}{l}-0.062^{*} \\
(0.030)\end{array}$ & $\begin{array}{l}-0.058^{*} \\
(0.027)\end{array}$ & $\begin{array}{c}-0.077^{* *} \\
(0.029)\end{array}$ & $\begin{array}{l}-0.074 * \\
(0.029)\end{array}$ & $\begin{array}{l}-0.058^{*} \\
(0.028)\end{array}$ & $\begin{array}{l}-0.073^{*} \\
(0.029)\end{array}$ & $\begin{array}{c}-0.105^{* *} \\
(0.032)\end{array}$ & $\begin{array}{l}-0.100^{*} \\
(0.043)\end{array}$ & $\begin{array}{c}-0.107^{* *} \\
(0.033)\end{array}$ & $\begin{array}{c}-0.092^{* *} \\
(0.031)\end{array}$ \\
\hline Trend & & & $\begin{array}{c}-0.692^{* *} \\
(0.123)\end{array}$ & $\begin{array}{c}-0.517^{* *} \\
(0.108)\end{array}$ & $\begin{array}{l}-0.261^{*} \\
(0.104)\end{array}$ & $\begin{array}{l}-0.261^{*} \\
(0.104)\end{array}$ & $\begin{array}{l}-0.251^{*} \\
(0.103)\end{array}$ & $\begin{array}{l}-0.263^{*} \\
(0.104)\end{array}$ & $\begin{array}{l}-0.262^{*} \\
(0.106)\end{array}$ & $\begin{array}{l}-0.251^{*} \\
(0.105)\end{array}$ & $\begin{array}{l}-0.251^{*} \\
(0.105)\end{array}$ & $\begin{array}{l}-0.250^{*} \\
(0.105)\end{array}$ & $\begin{array}{l}-0.251^{*} \\
(0.104)\end{array}$ \\
\hline $\begin{array}{l}\text { Father's } \\
\text { education }\end{array}$ & & & & & $\begin{array}{l}0.173^{* *} \\
(0.026)\end{array}$ & $\begin{array}{l}0.172^{* *} \\
(0.026)\end{array}$ & $\begin{array}{l}0.172^{* *} \\
(0.026)\end{array}$ & $\begin{array}{l}0.172^{* *} \\
(0.026)\end{array}$ & $\begin{array}{l}0.172^{* *} \\
(0.026)\end{array}$ & $\begin{array}{l}0.170^{* *} \\
(0.026)\end{array}$ & $\begin{array}{l}0.170^{* *} \\
(0.026)\end{array}$ & $\begin{array}{l}0.170^{* *} \\
(0.026)\end{array}$ & $\begin{array}{l}0.165^{* *} \\
(0.026)\end{array}$ \\
\hline $\begin{array}{l}\text { Grandfather's } \\
\text { education }\end{array}$ & & & & & $\begin{array}{l}0.089^{* *} \\
(0.018)\end{array}$ & $\begin{array}{l}0.088 * * \\
(0.018)\end{array}$ & $\begin{array}{l}0.089 * * \\
(0.018)\end{array}$ & $\begin{array}{l}0.089^{* *} \\
(0.018)\end{array}$ & $\begin{array}{l}0.086^{* *} \\
(0.018)\end{array}$ & $\begin{array}{l}0.085^{* *} \\
(0.018)\end{array}$ & $\begin{array}{l}0.085^{* *} \\
(0.018)\end{array}$ & $\begin{array}{l}0.085^{* *} \\
(0.018)\end{array}$ & $\begin{array}{l}0.080^{* *} \\
(0.018)\end{array}$ \\
\hline $\begin{array}{l}\text { Father age at } \\
\text { birth }\end{array}$ & & & & & & $\begin{array}{l}-0.001+ \\
(0.001)\end{array}$ & & & & $\begin{array}{l}-0.001 \\
(0.001)\end{array}$ & $\begin{array}{l}-0.001 \\
(0.001)\end{array}$ & $\begin{array}{l}-0.001 \\
(0.001)\end{array}$ & $\begin{array}{l}-0.002^{*} \\
(0.001)\end{array}$ \\
\hline $\begin{array}{l}\text { Mother age at } \\
\text { birth }\end{array}$ & & & & & & & $\begin{array}{l}-0.001 \\
(0.001)\end{array}$ & & & $\begin{array}{l}-0.001 \\
(0.001)\end{array}$ & $\begin{array}{l}-0.001 \\
(0.001)\end{array}$ & $\begin{array}{l}-0.001 \\
(0.001)\end{array}$ & $\begin{array}{c}0.000 \\
(0.001)\end{array}$ \\
\hline $\begin{array}{l}\text { Father age at } \\
\text { death }\end{array}$ & & & & & & & & $\begin{array}{l}-0.000 \\
(0.000)\end{array}$ & & & & & \\
\hline $\begin{array}{l}\text { Mother age at } \\
\text { Death }\end{array}$ & & & & & & & & & $\begin{array}{l}0.001+ \\
(0.000)\end{array}$ & $\begin{array}{c}0.001^{*} \\
(0.000)\end{array}$ & $\begin{array}{c}0.001^{*} \\
(0.000)\end{array}$ & $\begin{array}{c}0.001^{*} \\
(0.000)\end{array}$ & $\begin{array}{c}0.001^{*} \\
(0.000)\end{array}$ \\
\hline $\begin{array}{l}\text { Total no. of } \\
\text { siblings }\end{array}$ & & & & & & & & & & & $\begin{array}{l}-0.001 \\
(0.003)\end{array}$ & & \\
\hline $\begin{array}{l}\text { Share female } \\
\text { siblings }\end{array}$ & & & & & & & & & & & & $\begin{array}{l}-0.006 \\
(0.020)\end{array}$ & \\
\hline $\begin{array}{l}\text { Mother's rank } \\
\text { is one }\end{array}$ & & & & & & & & & & & & & $\begin{array}{c}-0.057^{* *} \\
(0.020)\end{array}$ \\
\hline Observations & 4,951 & 4,950 & 4,950 & 4,950 & 4,950 & 4,950 & 4,950 & 4,938 & 4,806 & 4,806 & 4,806 & 4,805 & 4,806 \\
\hline R-squared & 0.003 & 0.005 & 0.017 & 0.133 & 0.209 & 0.210 & 0.210 & 0.209 & 0.208 & 0.210 & 0.210 & 0.210 & 0.213 \\
\hline
\end{tabular}

Notes: Dependent variable is Education. Results by OLS. Brothers is number of brothers divided by 10. Birth year is man's birth year divided by 1,000. Robust standard errors clustered on household in parentheses. ${ }^{* *} / * /+$ significant at $1 \% / 5 \% / 10 \%$ level. 


\section{Table 6. Quantity-quality relationship in different subsamples}

\begin{tabular}{|c|c|c|c|}
\hline & \multicolumn{3}{|c|}{ Sample } \\
\hline & $\begin{array}{c}\text { (1) } \\
\text { Baseline }\end{array}$ & $\begin{array}{l}\text { (2) } \\
\text { Father not } \\
\text { educated }\end{array}$ & $\begin{array}{l}\text { (3) } \\
\text { Father and } \\
\text { grandfather } \\
\text { educated }\end{array}$ \\
\hline Brothers & $\begin{array}{c}-0.092^{* *} \\
(0.030)\end{array}$ & $\begin{array}{l}-0.067^{*} \\
(0.026)\end{array}$ & $\begin{array}{c}-0.419+ \\
(0.242)\end{array}$ \\
\hline Trend & $\begin{array}{l}-0.250^{*} \\
(0.105)\end{array}$ & $\begin{array}{c}-0.141 \\
(0.093)\end{array}$ & $\begin{array}{c}-0.552 \\
(0.642)\end{array}$ \\
\hline Father age at birth & $\begin{array}{c}-0.002^{* *} \\
(0.001)\end{array}$ & $\begin{array}{c}-0.001^{* *} \\
(0.001)\end{array}$ & $\begin{array}{l}-0.006 \\
(0.004)\end{array}$ \\
\hline Mother age at death & $\begin{array}{c}0.001^{*} \\
(0.000)\end{array}$ & $\begin{array}{l}0.001^{* *} \\
(0.000)\end{array}$ & $\begin{array}{l}-0.002 \\
(0.002)\end{array}$ \\
\hline Father's education & $\begin{array}{l}0.165^{* *} \\
(0.026)\end{array}$ & & \\
\hline Grandfather's education & $\begin{array}{l}0.081^{* *} \\
(0.018)\end{array}$ & $\begin{array}{l}0.099 \text { ** } \\
(0.019)\end{array}$ & \\
\hline Mother's rank is one & $\begin{array}{c}-0.056^{* *} \\
(0.020)\end{array}$ & $\begin{array}{l}-0.041^{*} \\
(0.018)\end{array}$ & $\begin{array}{c}-0.106 \\
(0.079)\end{array}$ \\
\hline Birth order FE & $\mathrm{Y}$ & Y & $\mathrm{Y}$ \\
\hline Lineage FE & Y & Y & Y \\
\hline Mean of dependent var. & 0.069 & 0.036 & 0.344 \\
\hline 1 brother less $\%$ of mean & 13.04 & 18.61 & 12.18 \\
\hline Observations & 4,806 & 4,234 & 349 \\
\hline R-squared & 0.213 & 0.109 & 0.185 \\
\hline
\end{tabular}

Notes: Dependent variable is Education. Estimation by OLS; standard errors clustered by household in parentheses. Brothers divided by 10. ${ }^{* *} \mathrm{p}<0.01,{ }^{*} \mathrm{p}<0.05,+\mathrm{p}<0.1$ 
Table 7. Heterogeneity in human capital investment

\begin{tabular}{lccc} 
Panel A. OLS Results & $(1)$ & $(2)$ & $(3)$ \\
& All & Studied, no pass & Pass \\
Brothers & $-0.092^{* *}$ & -0.027 & $-0.076^{* *}$ \\
& $(0.030)$ & $(0.018)$ & $(0.026)$ \\
Trend & $-0.251^{*}$ & $-0.098+$ & $-0.195^{*}$ \\
& $(0.104)$ & $(0.058)$ & $(0.096)$ \\
Father's age at birth & $-0.002^{* *}$ & $-0.001+$ & $-0.001^{* *}$ \\
& $(0.001)$ & $(0.000)$ & $(0.000)$ \\
Mother's age at death & $0.001^{*}$ & 0.000 & $0.001+$ \\
& $(0.000)$ & $0.000)$ & $0.161^{* *}$ \\
Father's education & $0.165^{* *}$ & $0.032^{*}$ & $(0.024)$ \\
& $(0.025)$ & $0.016)$ & $0.053^{* *}$ \\
Grandfather's education & $0.081^{* *}$ & $0.043^{* *}$ & $(0.016)$ \\
& $(0.018)$ & $-0.012)$ & $-0.038^{*}$ \\
Mother's rank is one & $-0.056^{* *}$ & $(0.014)$ & $(0.018)$ \\
& $(0.020)$ & & 4,697 \\
\hline Observations & & 4,582 & 0.096 \\
\hline
\end{tabular}

Notes: Dependent variable is Education. Estimation by OLS; standard errors clustered on household in parentheses. Brothers divided by $10{ }^{* *} \mathrm{p}<0.01,{ }^{*} \mathrm{p}<0.05,+\mathrm{p}<0.1$

\section{Panel B. Matching estimators}

No Education

Mean no. of brothers

3.240

3.165

3.231

Education

Mean no. of brothers

2.940

2.991

2.915

Difference

$-0.300$

$-0.174$

$-0.317$

(s.e.)

(0.102)

(0.161)

(0.113)

90\% Confidence Interval

$(-0.473,-0.248)$

$(-0.420,-0.010)$

$(-0.578,-0.152)$

No. of Education = 1

333

109

224

Notes: Results based on nearest-neighbor matching based on propensity score

Based on bootstrapping with bias-corrected confidence intervals. 
Table 8. The higher return effect on human capital accumulation: Instrumental-variables results

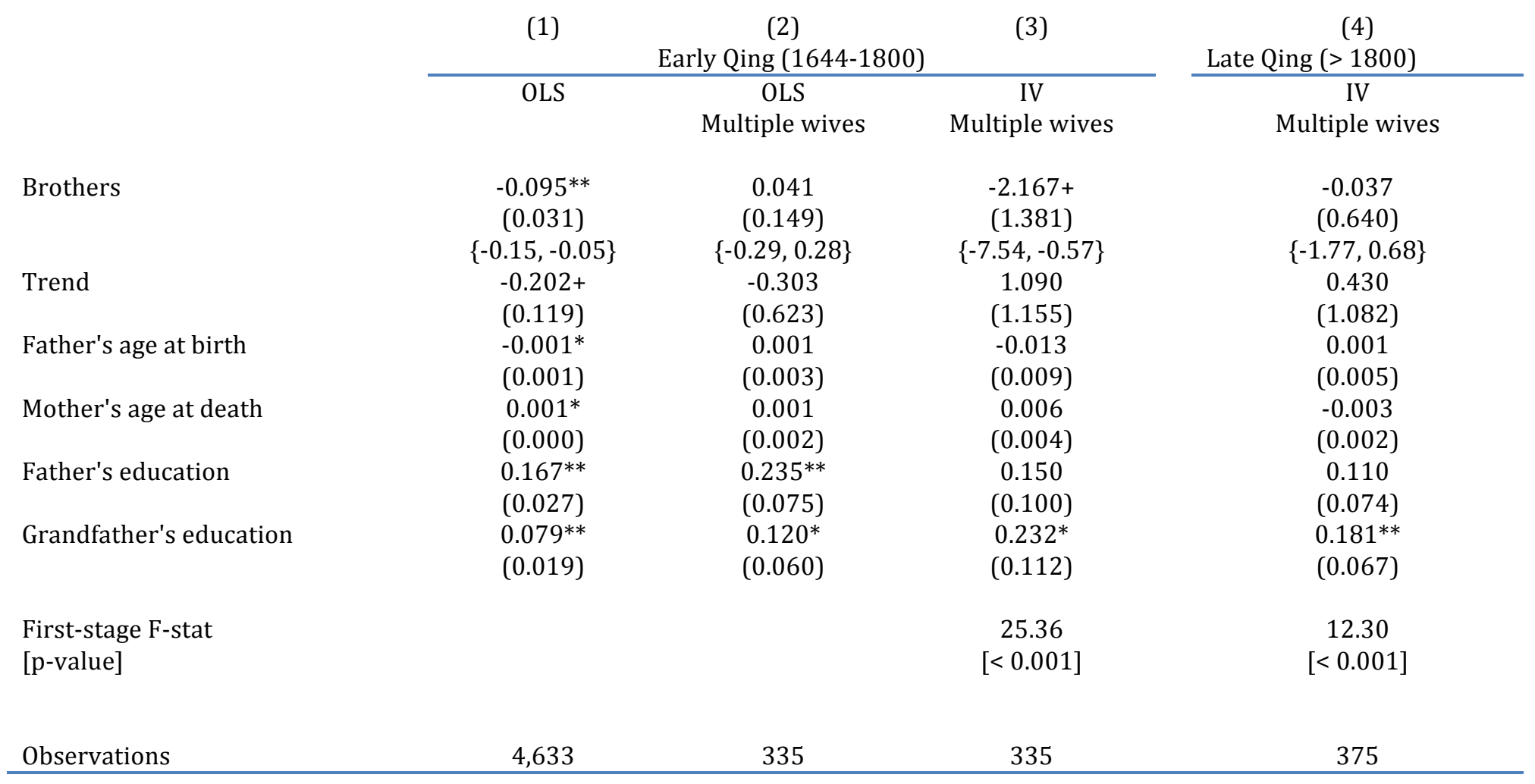

Notes: Dependent variable is Education. Estimation in columns 1 and 2 by OLS, in columns 3 and 4 by two-stage least squares. All specifications include birth order and lineage fixed effects. Robust standard errors clustered on household in parentheses. Given is the Angrist-Pischke F-statistic. Curly brackets give bias-corrected bootstrapped $90 \%$ confidence intervals. ${ }^{* *} / * /+$ means significant at the $1 \% / 5 \% / 10 \%$ level. 


\section{Table 9. Changing quantity-quality relationship between early to late Qing: results for alternative time breakpoints}

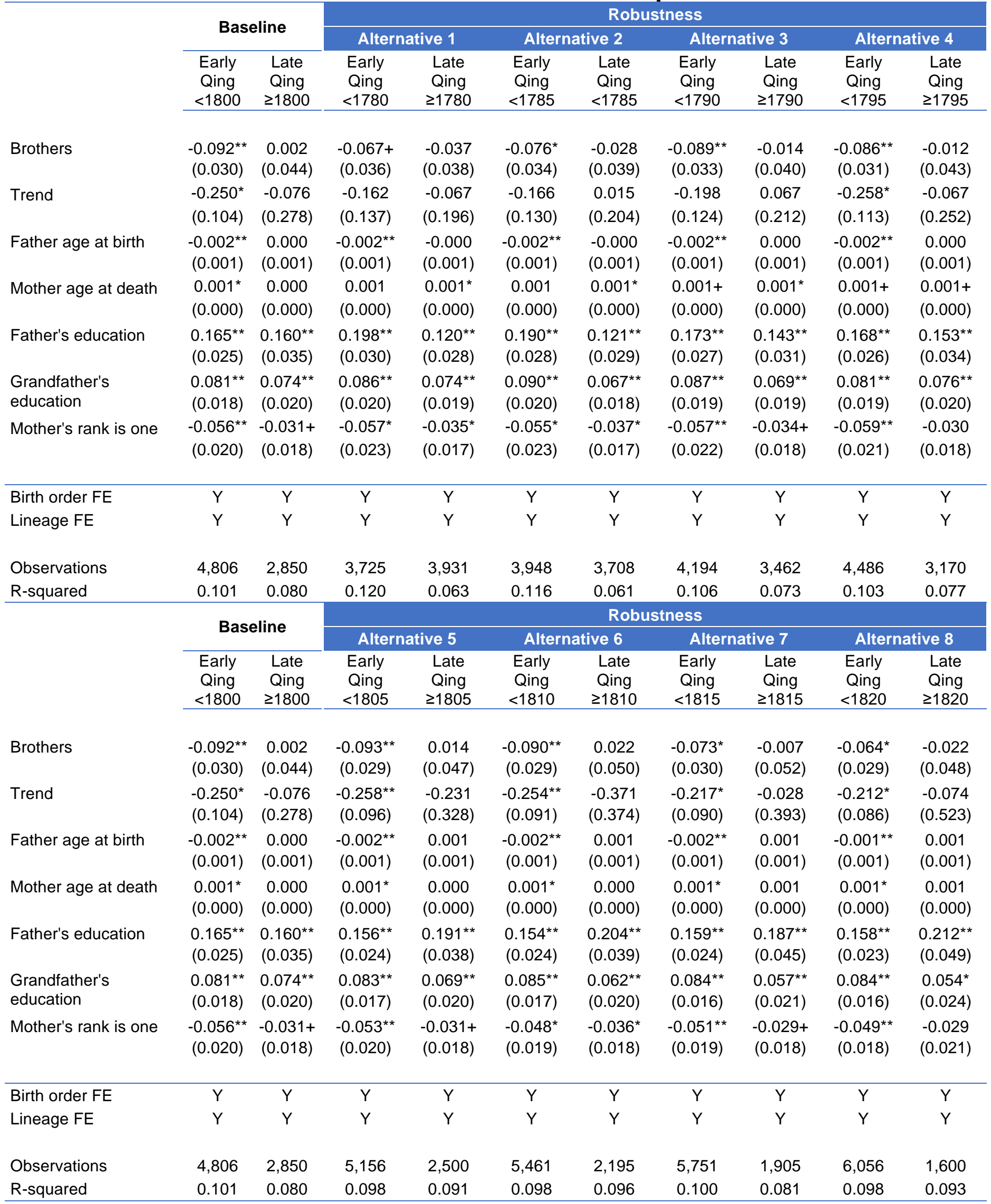

Notes: Dependent variable is Education. Estimation by OLS; Qing period divided as given in column headers. Brothers divided by 10. 
Figure 1. Frequency of birth year

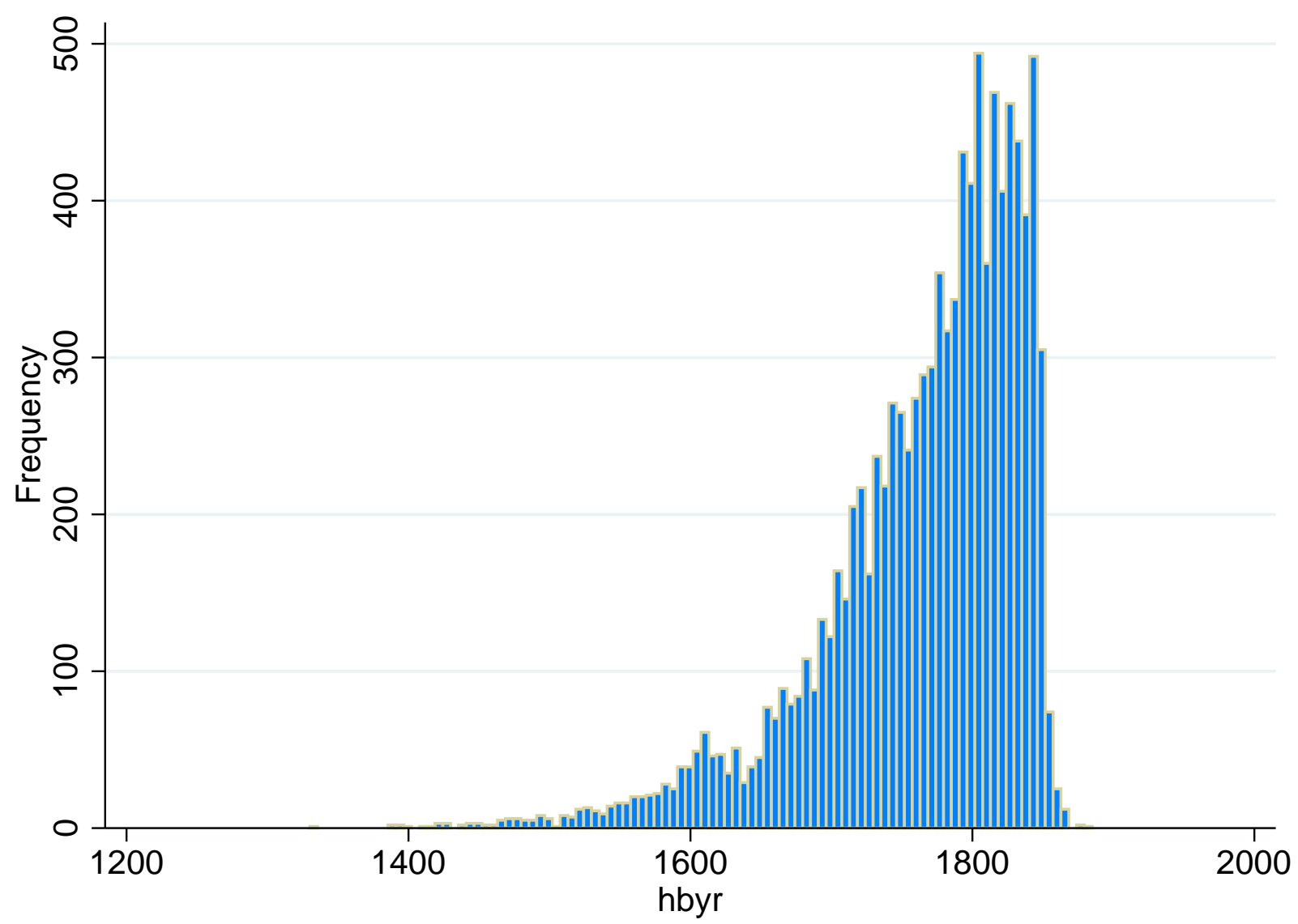


Figure 2. Fertility Curves All Lineages

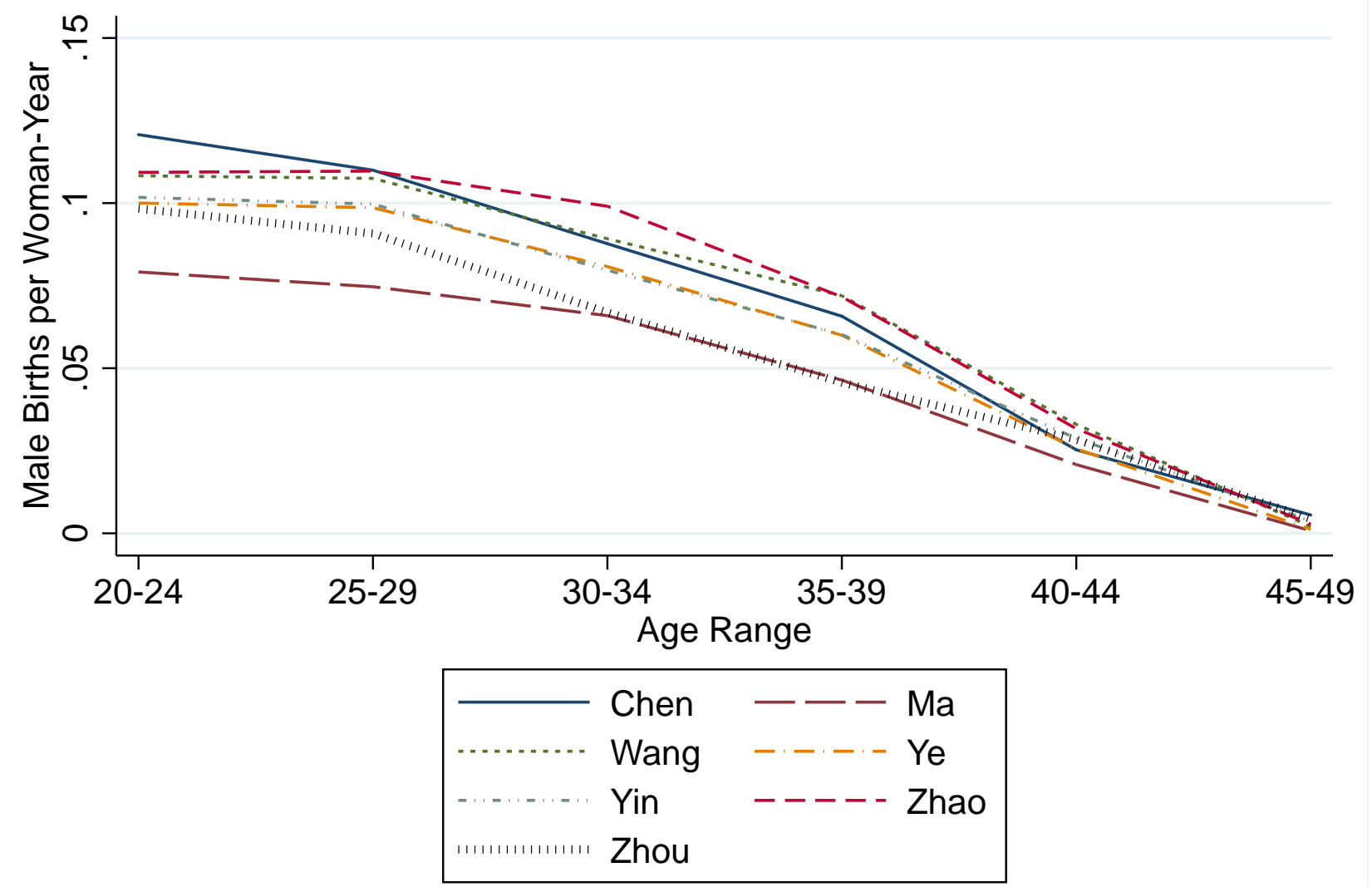


Figure 3. Quantity-quality relationship in Early versus Late Qing Education regressed on Brothers and covariates

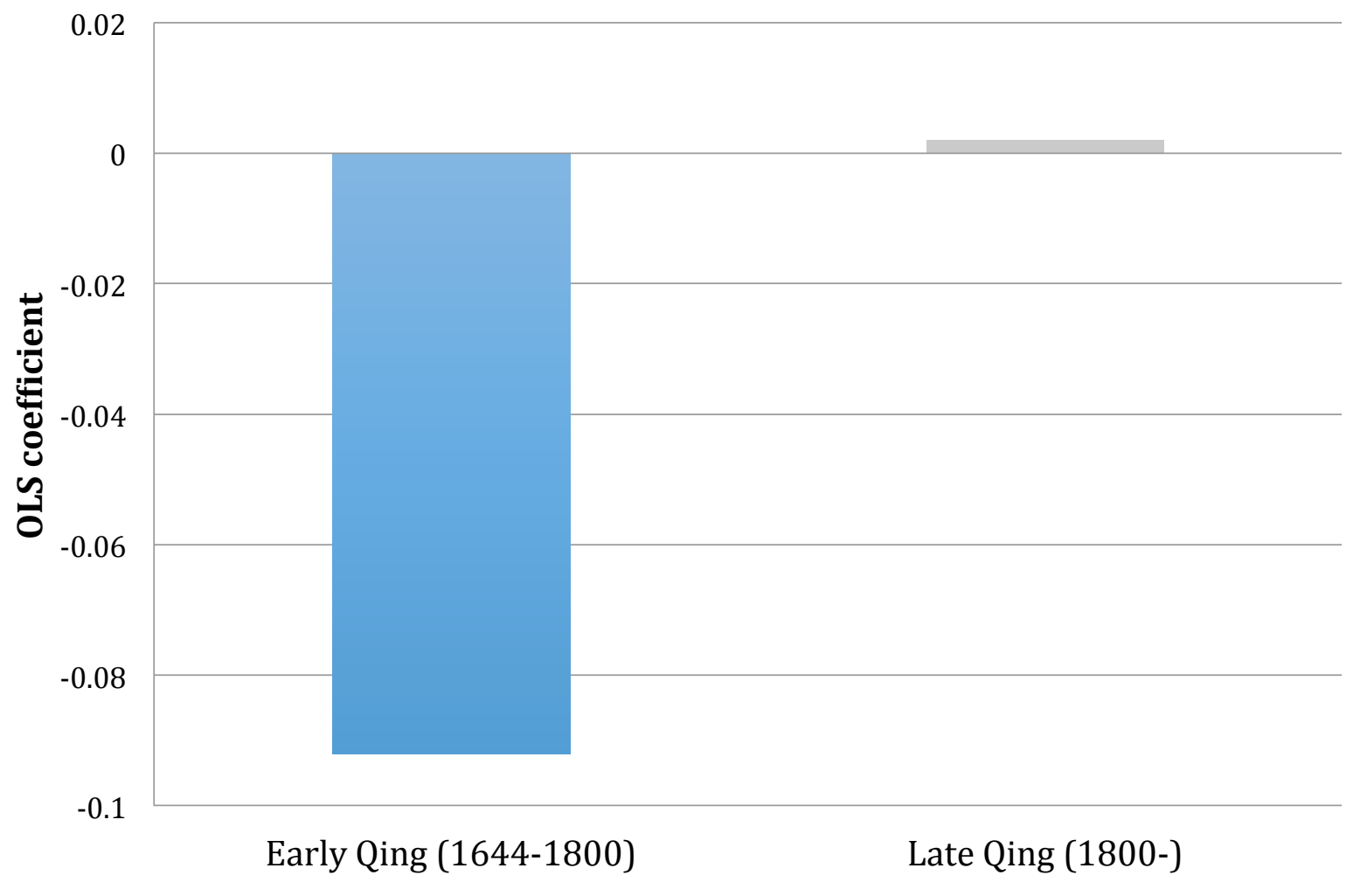


Figure 4. Early versus late Qing quantity-quality relationship for alternative time breakpoints

0.12

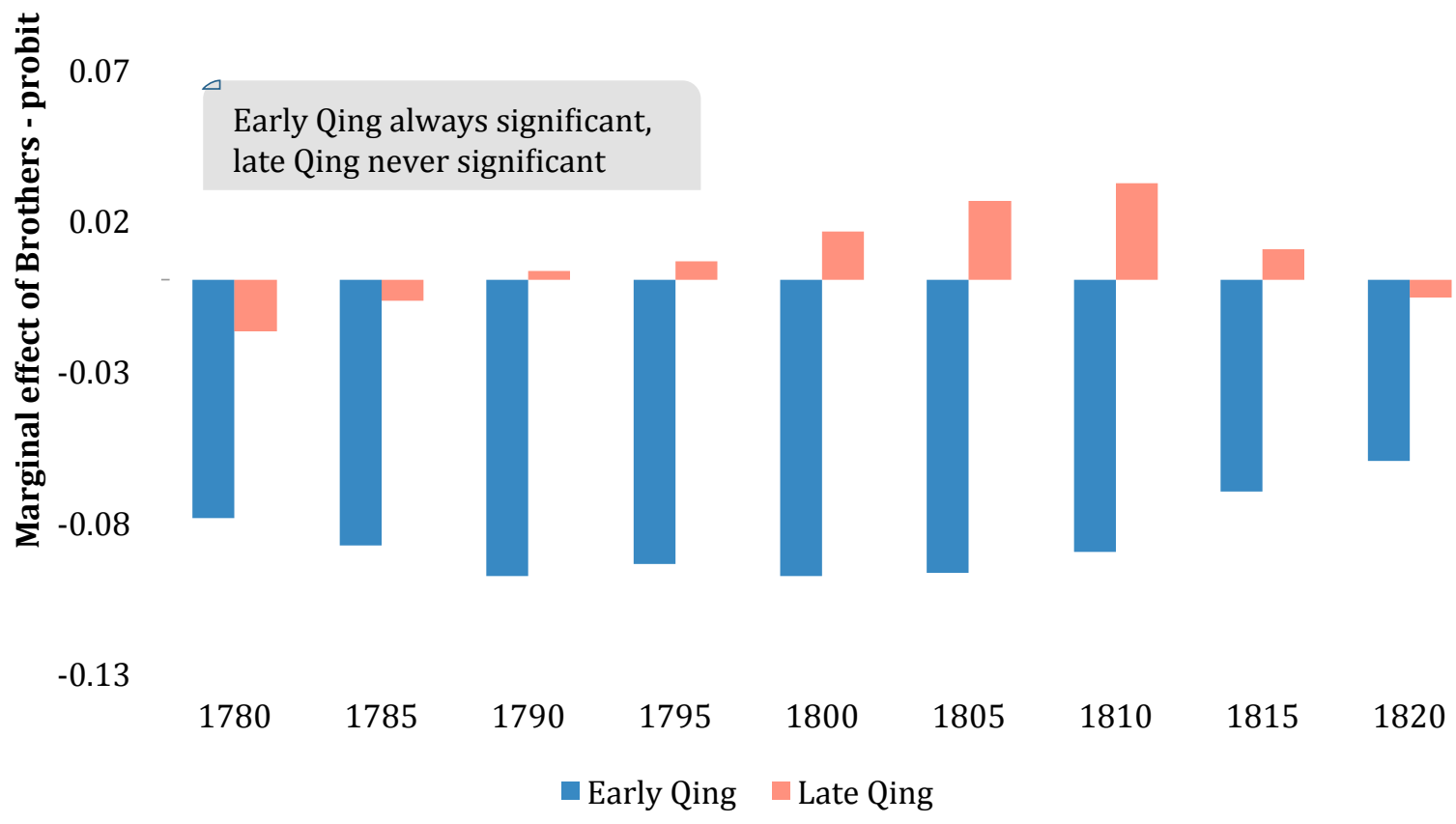


Table A. Characteristics of men and their wives

\begin{tabular}{|c|c|c|c|c|c|c|c|}
\hline & & Variable & Obs. & Mean & Std. & Min & $\operatorname{Max}$ \\
\hline \multicolumn{8}{|l|}{ Men } \\
\hline \multicolumn{8}{|c|}{ Demographics } \\
\hline & & Birth year & 9,787 & 1760.55 & 74.69 & 1298 & 1885 \\
\hline & & Birth month & 9,787 & 6.90 & 3.51 & 1 & 12 \\
\hline & & Death year & 8,142 & 1796.64 & 72.51 & 1348 & 1929 \\
\hline & & Death month & 8,142 & 6.53 & 3.41 & 1 & 12 \\
\hline \multicolumn{8}{|c|}{ Education } \\
\hline & & Education & 9,787 & 0.07 & 0.25 & 0 & 1 \\
\hline & & Father's education & 9,787 & 0.11 & 0.31 & 0 & 1 \\
\hline \multicolumn{8}{|c|}{ Wealth } \\
\hline & & Status & 9,786 & 1.65 & 3.67 & 0 & 22 \\
\hline & & No. of wives & 9,783 & 1.17 & 0.44 & 1 & 5 \\
\hline & & Variable & Obs. & Mean & Std. & Min & $\operatorname{Max}$ \\
\hline \multicolumn{8}{|l|}{ Women } \\
\hline \multicolumn{8}{|c|}{ Demographics } \\
\hline & & Birth year & 11,378 & 1766.24 & 75.31 & 1300 & 1887 \\
\hline & & Birth month & 11,378 & 6.75 & 3.47 & 1 & 12 \\
\hline & & Death year & 8,708 & 1797.10 & 73.66 & 1355 & 1930 \\
\hline & & Death month & 8,708 & 6.54 & 3.39 & 1 & 12 \\
\hline \multicolumn{8}{|c|}{ Other } \\
\hline & & Father's education & 6,179 & 0.08 & 0.28 & 0 & 1 \\
\hline & & Father's status & 6,179 & 1.86 & 4.74 & 0 & 22 \\
\hline
\end{tabular}


Table B. Characteristics of sons and daughters

\begin{tabular}{|c|c|c|c|c|c|c|c|}
\hline & & Variable & Obs. & Mean & Std. & Min & $\operatorname{Max}$ \\
\hline \multicolumn{8}{|l|}{ Sons } \\
\hline & \multicolumn{7}{|l|}{ Demographics } \\
\hline & & Birth order & 20,177 & 2.17 & 1.33 & 1 & 11 \\
\hline & & Birth year & 20,176 & 1792.21 & 74.18 & 1330 & 1909 \\
\hline & & Birth month & 20,175 & 6.79 & 3.49 & 1 & 12 \\
\hline & & Death year & 14,849 & 1806.75 & 67.67 & 1380 & 1929 \\
\hline & & Death month & 14,858 & 6.62 & 3.43 & 1 & 12 \\
\hline & \multicolumn{7}{|l|}{ Their fathers } \\
\hline & & Birth year & 20,177 & 1759.80 & 73.56 & 1298 & 1866 \\
\hline & & Birth month & 20,177 & 6.95 & 3.51 & 1 & 12 \\
\hline & & Age at death & 16,448 & 55.40 & 13.12 & 17 & 91 \\
\hline & & Education & 20,177 & 0.08 & 0.26 & 0 & 1 \\
\hline & \multicolumn{7}{|l|}{ Their mothers } \\
\hline & & Birth year & 20,177 & 1763.88 & 74.02 & 1300 & 1887 \\
\hline & & Birth month & 20,177 & 6.86 & 3.49 & 1 & 12 \\
\hline & & Age at death & 15,165 & 55.70 & 15.15 & 16 & 96 \\
\hline & & Variable & Obs. & Mean & Std. & Min & Max \\
\hline \multicolumn{8}{|l|}{ Daughters } \\
\hline & \multicolumn{7}{|l|}{ Demographics } \\
\hline & & Birth order & 11,150 & 1.81 & 1.09 & 1 & 10 \\
\hline & & Birth year & 2,443 & 1857.55 & 24.22 & 1615 & 1903 \\
\hline & & Birth month & 2,443 & 6.46 & 3.42 & 1 & 12 \\
\hline & & Death year & 1,418 & 1850.85 & 23.63 & 1654 & 1908 \\
\hline & & Death month & 1,420 & 7.06 & 3.31 & 1 & 12 \\
\hline & \multicolumn{7}{|l|}{ Their fathers } \\
\hline & & Birth year & 11,151 & 1770.63 & 66.09 & 1365 & 1866 \\
\hline & & Birth month & 11,151 & 6.99 & 3.53 & 1 & 12 \\
\hline & & Age at death & 8,541 & 55.37 & 13.42 & 15 & 90 \\
\hline & & Education & 11,151 & 0.09 & 0.28 & 0 & 1 \\
\hline & \multicolumn{7}{|l|}{ Their mothers } \\
\hline & & Birth year & 11,151 & 1774.78 & 66.55 & 1369 & 1870 \\
\hline & & Birth month & 11,151 & 6.86 & 3.50 & 1 & 12 \\
\hline & & Age at death & 7,784 & 55.87 & 15.44 & 11 & 96 \\
\hline
\end{tabular}


Table C. Summary statistics by lineage

\begin{tabular}{|c|c|c|c|c|c|c|c|}
\hline $\begin{array}{l}\text { Lineage } \\
\text { name }\end{array}$ & & Education & Brothers & $\begin{array}{l}\text { Total } \\
\text { Siblings }\end{array}$ & $\begin{array}{c}\text { Share female } \\
\text { siblings }\end{array}$ & $\begin{array}{l}\text { Father's } \\
\text { education }\end{array}$ & $\begin{array}{l}\text { Mother's age } \\
\text { at death }\end{array}$ \\
\hline \multirow[t]{3}{*}{ Chen } & Obs. & 291 & 291 & 291 & 291 & 291 & 250 \\
\hline & Mean & 0.003 & 3.716 & 5.495 & 0.266 & 0.017 & 61.340 \\
\hline & Std. & 0.059 & 1.831 & 2.732 & 0.207 & 0.130 & 13.631 \\
\hline \multirow[t]{3}{*}{$M a$} & Obs. & 627 & 627 & 627 & 627 & 627 & 621 \\
\hline & Mean & 0.327 & 2.691 & 4.396 & 0.302 & 0.415 & 60.359 \\
\hline & Std. & 0.469 & 1.389 & 2.177 & 0.221 & 0.493 & 17.188 \\
\hline \multirow[t]{3}{*}{ Wang } & Obs. & 4681 & 4681 & 4681 & 4681 & 4681 & 4333 \\
\hline & Mean & 0.034 & 3.435 & 4.996 & 0.267 & 0.075 & 57.707 \\
\hline & Std. & 0.181 & 1.640 & 2.183 & 0.200 & 0.263 & 14.113 \\
\hline \multirow[t]{3}{*}{$Y e$} & Obs. & 1607 & 1607 & 1607 & 1606 & 1607 & 1480 \\
\hline & Mean & 0.101 & 3.103 & 4.711 & 0.274 & 0.156 & 58.911 \\
\hline & Std. & 0.302 & 1.617 & 2.121 & 0.216 & 0.363 & 15.908 \\
\hline \multirow[t]{3}{*}{ Yin } & Obs. & 604 & 604 & 604 & 604 & 604 & 567 \\
\hline & Mean & 0.026 & 3.194 & 4.796 & 0.271 & 0.040 & 59.087 \\
\hline & Std. & 0.161 & 1.523 & 2.234 & 0.229 & 0.195 & 13.824 \\
\hline \multirow[t]{3}{*}{ Zhao } & Obs. & 769 & 769 & 769 & 769 & 769 & 693 \\
\hline & Mean & 0.017 & 3.331 & 4.831 & 0.265 & 0.051 & 58.245 \\
\hline & Std. & 0.129 & 1.495 & 2.151 & 0.193 & 0.220 & 14.184 \\
\hline \multirow[t]{3}{*}{ Zhou } & Obs. & 314 & 314 & 313 & 313 & 314 & 304 \\
\hline & Mean & 0.022 & 2.834 & 3.738 & 0.174 & 0.038 & 58.270 \\
\hline & Std. & 0.148 & 1.568 & 2.100 & 0.220 & 0.192 & 12.883 \\
\hline \multirow[t]{3}{*}{ Total } & Obs. & 8893 & 8893 & 8892 & 8891 & 8893 & 8248 \\
\hline & Mean & 0.063 & 3.285 & 4.846 & 0.267 & 0.106 & 58.394 \\
\hline & Std. & 0.244 & 1.621 & 2.208 & 0.208 & 0.308 & 14.656 \\
\hline
\end{tabular}


Table D. Quantity-quality relationship in early Qing 1644-1800 - Probit results

\begin{tabular}{|c|c|c|c|c|c|c|c|c|c|c|c|c|c|}
\hline \multirow[b]{3}{*}{ Brothers } & (1) & (2) & (3) & (4) & (5) & (6) & (7) & $(8)$ & (9) & \multirow[t]{2}{*}{ (10) } & (11) & (12) & \multirow{2}{*}{$\begin{array}{c}\text { (13) } \\
\text { Baseline }\end{array}$} \\
\hline & & $\begin{array}{l}\text { Birth } \\
\text { order }\end{array}$ & Trend & $\begin{array}{l}\text { Lineage } \\
\text { FE }\end{array}$ & $\begin{array}{c}\text { Lineal } \\
\text { HC }\end{array}$ & \multicolumn{2}{|c|}{$\begin{array}{l}\text { Early start and } \\
\text { spacing }\end{array}$} & \multicolumn{2}{|c|}{ Longevity } & & \multicolumn{2}{|c|}{ Sibship } & \\
\hline & $\begin{array}{c}-0.742^{* *} \\
(0.238)\end{array}$ & $\begin{array}{l}-1.181^{* *} \\
(0.312)\end{array}$ & $\begin{array}{c}-1.141^{* *} \\
(0.308)\end{array}$ & $\begin{array}{l}-0.571+ \\
(0.309)\end{array}$ & $\begin{array}{l}-0.553+ \\
(0.307)\end{array}$ & $\begin{array}{l}-0.787^{*} \\
(0.321)\end{array}$ & $\begin{array}{l}-0.714^{*} \\
(0.320)\end{array}$ & $\begin{array}{c}-0.578+ \\
(0.307)\end{array}$ & $\begin{array}{l}-0.774^{*} \\
(0.317)\end{array}$ & $\begin{array}{c}-1.137^{* *} \\
(0.342)\end{array}$ & $\begin{array}{c}-1.207^{* *} \\
(0.410)\end{array}$ & $\begin{array}{c}-1.065^{* *} \\
(0.349)\end{array}$ & $\begin{array}{c}-1.034^{* *} \\
(0.327)\end{array}$ \\
\hline Trend & & & $\begin{array}{c}-4.989 * * \\
(0.800)\end{array}$ & $\begin{array}{c}-4.274^{* *} \\
(0.824)\end{array}$ & $\begin{array}{l}-2.094^{*} \\
(0.948)\end{array}$ & $\begin{array}{l}-2.093^{*} \\
(0.961)\end{array}$ & $\begin{array}{l}-1.961^{*} \\
(0.950)\end{array}$ & $\begin{array}{l}-2.084^{*} \\
(0.945)\end{array}$ & $\begin{array}{l}-2.229^{*} \\
(0.948)\end{array}$ & $\begin{array}{l}-2.134^{*} \\
(0.949)\end{array}$ & $\begin{array}{l}-2.117^{*} \\
(0.946)\end{array}$ & $\begin{array}{l}-2.253^{*} \\
(0.962)\end{array}$ & $\begin{array}{l}-2.067^{*} \\
(0.954)\end{array}$ \\
\hline $\begin{array}{l}\text { Father's } \\
\text { education }\end{array}$ & & & & & $\begin{array}{l}0.816^{* *} \\
(0.104)\end{array}$ & $\begin{array}{l}0.810^{* *} \\
(0.104)\end{array}$ & $\begin{array}{l}0.814^{* *} \\
(0.104)\end{array}$ & $\begin{array}{l}0.813^{* *} \\
(0.105)\end{array}$ & $\begin{array}{l}0.801^{* *} \\
(0.104)\end{array}$ & $\begin{array}{l}0.790^{* *} \\
(0.103)\end{array}$ & $\begin{array}{l}0.786^{* *} \\
(0.104)\end{array}$ & $\begin{array}{l}0.789 * * \\
(0.103)\end{array}$ & $\begin{array}{l}0.750^{* *} \\
(0.101)\end{array}$ \\
\hline $\begin{array}{l}\text { Grandfather's } \\
\text { education }\end{array}$ & & & & & $\begin{array}{l}0.555^{* *} \\
(0.096)\end{array}$ & $\begin{array}{l}0.554^{* *} \\
(0.096)\end{array}$ & $\begin{array}{l}0.560 * * \\
(0.096)\end{array}$ & $\begin{array}{l}0.555^{* *} \\
(0.096)\end{array}$ & $\begin{array}{l}0.534^{* *} \\
(0.096)\end{array}$ & $\begin{array}{l}0.536^{* *} \\
(0.096)\end{array}$ & $\begin{array}{l}0.534^{* *} \\
(0.097)\end{array}$ & $\begin{array}{l}0.531^{* *} \\
(0.096)\end{array}$ & $\begin{array}{l}0.504^{* *} \\
(0.096)\end{array}$ \\
\hline $\begin{array}{l}\text { Father's age at } \\
\text { birth }\end{array}$ & & & & & & $\begin{array}{l}-0.012^{*} \\
(0.006)\end{array}$ & & & & $\begin{array}{l}-0.009 \\
(0.008)\end{array}$ & $\begin{array}{l}-0.009 \\
(0.007)\end{array}$ & $\begin{array}{l}-0.014^{*} \\
(0.006)\end{array}$ & $\begin{array}{c}-0.022^{* *} \\
(0.006)\end{array}$ \\
\hline $\begin{array}{l}\text { Mother's age at } \\
\text { birth }\end{array}$ & & & & & & & $\begin{array}{l}-0.012+ \\
(0.007)\end{array}$ & & & $\begin{array}{l}-0.011 \\
(0.010)\end{array}$ & $\begin{array}{l}-0.010 \\
(0.009)\end{array}$ & & \\
\hline $\begin{array}{l}\text { Father's age at } \\
\text { death }\end{array}$ & & & & & & & & $\begin{array}{c}0.002 \\
(0.003)\end{array}$ & & & & & \\
\hline $\begin{array}{l}\text { Mother's age at } \\
\text { death }\end{array}$ & & & & & & & & & $\begin{array}{l}0.008^{* *} \\
(0.003)\end{array}$ & $\begin{array}{l}0.009^{* *} \\
(0.003)\end{array}$ & $\begin{array}{l}0.009^{* *} \\
(0.003)\end{array}$ & $\begin{array}{l}0.008^{* *} \\
(0.003)\end{array}$ & $\begin{array}{l}0.008^{* *} \\
(0.003)\end{array}$ \\
\hline $\begin{array}{l}\text { Total no. of } \\
\text { siblings }\end{array}$ & & & & & & & & & & & $\begin{array}{c}0.009 \\
(0.029)\end{array}$ & & \\
\hline $\begin{array}{l}\text { Share female } \\
\text { siblings }\end{array}$ & & & & & & & & & & & & $\begin{array}{c}0.036 \\
(0.184)\end{array}$ & \\
\hline Mother's rank & & & & & & & & & & & & & $\begin{array}{c}-0.435^{* *} \\
(0.122)\end{array}$ \\
\hline $\begin{array}{l}\text { Brothers } \\
\text { marginal } \\
\text { effect }\end{array}$ & $-0.096^{* *}$ & $-0.153^{* *}$ & $-0.145^{* *}$ & $-0.062+$ & $-0.052+$ & $-0.074^{*}$ & $-0.067^{*}$ & $-0.055+$ & $-0.074^{*}$ & $0.109^{* *}$ & $-0.115^{* *}$ & $-0.102^{* *}$ & $-0.098^{* *}$ \\
\hline Observations & 4,951 & 4,926 & 4,926 & 4,926 & 4,926 & 4,926 & 4,926 & 4,914 & 4,782 & 4,782 & 4,782 & 4,781 & 4,782 \\
\hline
\end{tabular}


Table E. Quantity-quality relationship in Early Qing - robustness

\begin{tabular}{|c|c|c|c|c|}
\hline & $\begin{array}{c}\text { (1) } \\
\text { Baseline }\end{array}$ & $\begin{array}{c}\text { (2) } \\
\text { Generalized } \\
\text { Time Trend }\end{array}$ & $\begin{array}{l}\text { (3) } \\
\text { Lineage } \\
\text { Trends }\end{array}$ & $\begin{array}{c}\text { (4) } \\
\text { Dynasty } \\
\text { Change }\end{array}$ \\
\hline Brothers & $\begin{array}{c}-0.092^{* *} \\
(0.028) \\
(0.031) \\
(0.023) \\
(0.031)\end{array}$ & $\begin{array}{c}-0.091^{* *} \\
(0.027) \\
(0.027) \\
(0.031) \\
(0.024)\end{array}$ & $\begin{array}{c}-0.098^{* *} \\
(0.030) \\
(0.026) \\
(0.029) \\
(0.026)\end{array}$ & $\begin{array}{c}-0.092^{* *} \\
(0.034) \\
(0.025) \\
(0.028) \\
(0.030)\end{array}$ \\
\hline Father's education & $\begin{array}{l}0.165^{* *} \\
(0.026) \\
(0.020) \\
(0.022) \\
(0.023)\end{array}$ & $\begin{array}{l}0.164^{* *} \\
(0.021) \\
(0.024) \\
(0.022) \\
(0.018)\end{array}$ & $\begin{array}{l}0.167^{* *} \\
(0.025) \\
(0.021) \\
(0.021) \\
(0.024)\end{array}$ & $\begin{array}{l}0.165^{* *} \\
(0.028) \\
(0.019) \\
(0.026) \\
(0.018)\end{array}$ \\
\hline Grandfather's education & $\begin{array}{l}0.081^{* *} \\
(0.016) \\
(0.015) \\
(0.017) \\
(0.019)\end{array}$ & $\begin{array}{l}0.081^{* *} \\
(0.020) \\
(0.017) \\
(0.013) \\
(0.013)\end{array}$ & $\begin{array}{c}0.083^{* *} \\
(0.015) \\
(0.018) \\
(0.015) \\
(0.015)\end{array}$ & $\begin{array}{l}0.080^{* *} \\
(0.017) \\
(0.014) \\
(0.018) \\
(0.016)\end{array}$ \\
\hline Father's age at birth & $\begin{array}{c}-0.002^{* *} \\
(0.001) \\
(0.000) \\
(0.001) \\
(0.001)\end{array}$ & $\begin{array}{c}-0.002^{* *} \\
(0.001) \\
(0.001) \\
(0.000) \\
(0.000)\end{array}$ & $\begin{array}{c}-0.002^{* *} \\
(0.001) \\
(0.001) \\
(0.000) \\
(0.000)\end{array}$ & $\begin{array}{c}-0.002^{* *} \\
(0.001) \\
(0.000) \\
(0.001) \\
(0.001)\end{array}$ \\
\hline Mother's age at death & $\begin{array}{c}0.001^{*} \\
(0.000) \\
(0.000) \\
(0.000) \\
(0.000)\end{array}$ & $\begin{array}{l}0.001^{* *} \\
(0.000) \\
(0.000) \\
(0.000) \\
(0.000)\end{array}$ & $\begin{array}{c}0.001^{*} \\
(0.000) \\
(0.000) \\
(0.000) \\
(0.000)\end{array}$ & $\begin{array}{c}0.001^{*} \\
(0.000) \\
(0.000) \\
(0.000) \\
(0.000)\end{array}$ \\
\hline Mother rank equals one & $\begin{array}{c}-0.056^{* *} \\
(0.017) \\
(0.017) \\
(0.021) \\
(0.016)\end{array}$ & $\begin{array}{c}-0.055^{* *} \\
(0.019) \\
(0.017) \\
(0.017) \\
(0.016)\end{array}$ & $\begin{array}{c}-0.056^{* *} \\
(0.020) \\
(0.021) \\
(0.020) \\
(0.018)\end{array}$ & $\begin{array}{c}-0.057^{* *} \\
(0.020) \\
(0.017) \\
(0.016) \\
(0.019)\end{array}$ \\
\hline Trend & $\begin{array}{c}-0.250^{*} \\
(0.100) \\
(0.087) \\
(0.097) \\
(0.091)\end{array}$ & & & $\begin{array}{c}-0.269 * * \\
(0.095) \\
(0.097) \\
(0.114) \\
(0.104)\end{array}$ \\
\hline $\begin{array}{l}\text { Birth order FE } \\
\text { Lineage FE } \\
\text { Decade FE } \\
\text { Lineage x Trend FE } \\
\text { Reign Change Controls } \\
\text { Observations }\end{array}$ & $\begin{array}{c}\mathrm{Y} \\
\mathrm{Y} \\
\mathrm{N} \\
\mathrm{N} \\
\mathrm{N} \\
4,806\end{array}$ & $\begin{array}{c}\mathrm{Y} \\
\mathrm{Y} \\
\mathrm{Y} \\
\mathrm{N} \\
\mathrm{N} \\
4,806\end{array}$ & $\begin{array}{c}\mathrm{Y} \\
\mathrm{Y} \\
\mathrm{N} \\
\mathrm{Y} \\
\mathrm{N} \\
4,806\end{array}$ & $\begin{array}{c}\mathrm{Y} \\
\mathrm{Y} \\
\mathrm{N} \\
\mathrm{N} \\
\mathrm{Y} \\
4,806\end{array}$ \\
\hline
\end{tabular}

Notes: Dep. Var. Education. Estimation by OLS. Alternative standard errors in parentheses. First clustered on household (1,297 clusters); second clustered on household and decade (clusters: 1,297/16); third clustered on lineage and decade (clusters: 7/16); fourth on household and cohort of the lineage (clusters: 1,297/11). ${ }^{* *} / * /+$ significant at $1 \% / 5 \% / 10 \%$ level based on first set of standard errors. 
Table F: Lineage differences and the child quantity-quality relationship

Early Qing (1644 to 1800)

\begin{tabular}{|c|c|c|c|c|c|c|c|c|}
\hline & $\begin{array}{c}(1) \\
\text { All Lineages }\end{array}$ & $\begin{array}{c}(2) \\
\text { No Chen }\end{array}$ & $\begin{array}{c}(3) \\
\text { No } M a\end{array}$ & $\begin{array}{c}(4) \\
\text { No Wang }\end{array}$ & $\begin{array}{c}(5) \\
\text { No } Y e\end{array}$ & $\begin{array}{c}(6) \\
\text { No Yin }\end{array}$ & $\begin{array}{c}(7) \\
\text { No Zhao }\end{array}$ & $\begin{array}{c}(8) \\
\text { No Zhou }\end{array}$ \\
\hline Brothers & $\begin{array}{c}-0.092^{* *} \\
(0.030)\end{array}$ & $\begin{array}{c}-0.095^{* *} \\
(0.031)\end{array}$ & $\begin{array}{l}-0.062^{*} \\
(0.027)\end{array}$ & $\begin{array}{c}-0.100+ \\
(0.056)\end{array}$ & $\begin{array}{c}-0.090^{* *} \\
(0.031)\end{array}$ & $\begin{array}{c}-0.098^{* *} \\
(0.032)\end{array}$ & $\begin{array}{c}-0.111^{* *} \\
(0.031)\end{array}$ & $\begin{array}{c}-0.090^{* *} \\
(0.031)\end{array}$ \\
\hline Trend & $\begin{array}{l}-0.250^{*} \\
(0.104)\end{array}$ & $\begin{array}{c}-0.253^{*} \\
(0.107)\end{array}$ & $\begin{array}{c}-0.198^{*} \\
(0.097)\end{array}$ & $\begin{array}{c}-0.000 \\
(0.163)\end{array}$ & $\begin{array}{c}-0.377^{* *} \\
(0.108)\end{array}$ & $\begin{array}{l}-0.270^{*} \\
(0.113)\end{array}$ & $\begin{array}{c}-0.265^{*} \\
(0.114)\end{array}$ & $\begin{array}{c}-0.246^{*} \\
(0.108)\end{array}$ \\
\hline Father's age at birth & $\begin{array}{c}-0.002^{* *} \\
(0.001)\end{array}$ & $\begin{array}{c}-0.002^{* *} \\
(0.001)\end{array}$ & $\begin{array}{l}-0.001^{*} \\
(0.000)\end{array}$ & $\begin{array}{c}-0.003^{* *} \\
(0.001)\end{array}$ & $\begin{array}{c}-0.002^{* *} \\
(0.001)\end{array}$ & $\begin{array}{c}-0.002^{* *} \\
(0.001)\end{array}$ & $\begin{array}{c}-0.002^{* *} \\
(0.001)\end{array}$ & $\begin{array}{c}-0.002^{* *} \\
(0.001)\end{array}$ \\
\hline Mother's age at death & $\begin{array}{l}0.001^{*} \\
(0.000)\end{array}$ & $\begin{array}{c}0.001^{*} \\
(0.000)\end{array}$ & $\begin{array}{l}0.001^{* *} \\
(0.000)\end{array}$ & $\begin{array}{c}0.001 \\
(0.000)\end{array}$ & $\begin{array}{c}0.001^{*} \\
(0.000)\end{array}$ & $\begin{array}{c}0.001^{*} \\
(0.000)\end{array}$ & $\begin{array}{c}0.001^{*} \\
(0.000)\end{array}$ & $\begin{array}{c}0.001^{*} \\
(0.000)\end{array}$ \\
\hline Father's education & $\begin{array}{l}0.165^{* *} \\
(0.025)\end{array}$ & $\begin{array}{c}0.165^{* *} \\
(0.026)\end{array}$ & $\begin{array}{c}0.159^{* *} \\
(0.027)\end{array}$ & $\begin{array}{l}0.159^{* *} \\
(0.034)\end{array}$ & $\begin{array}{l}0.163^{* *} \\
(0.030)\end{array}$ & $\begin{array}{c}0.164^{* *} \\
(0.026)\end{array}$ & $\begin{array}{c}0.174^{* *} \\
(0.026)\end{array}$ & $\begin{array}{l}0.166^{* *} \\
(0.026)\end{array}$ \\
\hline Grandfather's education & $\begin{array}{l}0.081^{* *} \\
(0.018)\end{array}$ & $\begin{array}{c}0.082^{* *} \\
(0.018)\end{array}$ & $\begin{array}{c}0.048^{* *} \\
(0.017)\end{array}$ & $\begin{array}{l}0.128^{* *} \\
(0.027)\end{array}$ & $\begin{array}{l}0.090^{* *} \\
(0.022)\end{array}$ & $\begin{array}{c}0.082^{* *} \\
(0.018)\end{array}$ & $\begin{array}{c}0.075^{* *} \\
(0.019)\end{array}$ & $\begin{array}{c}0.081^{* *} \\
(0.018)\end{array}$ \\
\hline Mother's rank is one & $\begin{array}{c}-0.056^{* *} \\
(0.020)\end{array}$ & $\begin{array}{c}-0.058^{* *} \\
(0.021)\end{array}$ & $\begin{array}{c}-0.068^{* *} \\
(0.021)\end{array}$ & $\begin{array}{c}-0.023 \\
(0.028)\end{array}$ & $\begin{array}{l}-0.060^{*} \\
(0.024)\end{array}$ & $\begin{array}{c}-0.056^{* *} \\
(0.021)\end{array}$ & $\begin{array}{c}-0.058^{* *} \\
(0.021)\end{array}$ & $\begin{array}{c}-0.060^{* *} \\
(0.021)\end{array}$ \\
\hline Observations & 4,806 & 4,651 & 4,423 & 2,341 & 3,983 & 4,455 & 4,353 & 4,630 \\
\hline
\end{tabular}

Notes: Dependent variable is Education. Estimation by OLS. All specifications include birth order and lineage fixed effects. Robust standard errors clustered on household in parentheses. ${ }^{* *} \mathrm{p}<0.01,{ }^{*} \mathrm{p}<0.05,+\mathrm{p}<0.1$. Mean Education of the seven lineages in the sample of column 1 are as follows (in \%): Chen 0.6, Ma 36.0, Wang 4.1, Ye 9.0, Yin 2.0, Zhao 2.0, Zhou 1.1. 


\section{Table G. Fertility and human capital versus other investments}

\begin{tabular}{|c|c|c|c|c|}
\hline Dependent Variable & $\begin{array}{c}\text { (1) } \\
\text { Education }\end{array}$ & $\begin{array}{c}\text { (2) } \\
\text { Educated and } \\
\text { Purchased } \\
\text { Degrees }\end{array}$ & $\begin{array}{c}\text { (3) } \\
\text { Educated and } \\
\text { Purchased } \\
\text { Degrees }\end{array}$ & $\begin{array}{c}\text { (4) } \\
\text { Educated and } \\
\text { Purchased } \\
\text { Degrees }\end{array}$ \\
\hline Brothers & $\begin{array}{c}-0.092^{* *} \\
(0.030)\end{array}$ & $\begin{array}{c}-0.109^{* *} \\
(0.036)\end{array}$ & $\begin{array}{c}-0.136^{* *} \\
(0.032)\end{array}$ & $\begin{array}{c}-0.136^{* *} \\
(0.032)\end{array}$ \\
\hline Brothers $\times$ Purchase Degree & & & $\begin{array}{l}1.990^{* *} \\
(0.111)\end{array}$ & $\begin{array}{l}1.994^{* *} \\
(0.139)\end{array}$ \\
\hline Trend & $\begin{array}{l}-0.250^{*} \\
(0.104)\end{array}$ & $\begin{array}{c}-0.396^{* *} \\
(0.113)\end{array}$ & $\begin{array}{c}-0.321^{* *} \\
(0.107)\end{array}$ & $\begin{array}{c}-0.321^{* *} \\
(0.107)\end{array}$ \\
\hline Father's education & $\begin{array}{l}0.165^{* *} \\
(0.025)\end{array}$ & $\begin{array}{l}0.203^{* *} \\
(0.027)\end{array}$ & $\begin{array}{l}0.187^{* *} \\
(0.026)\end{array}$ & $\begin{array}{l}0.185^{* *} \\
(0.027)\end{array}$ \\
\hline $\begin{array}{l}\text { Father's education } \\
\times \text { Purchase Degree }\end{array}$ & & & & $\begin{array}{c}0.035 \\
(0.066)\end{array}$ \\
\hline Grandfather's education & $\begin{array}{l}0.081^{* *} \\
(0.018)\end{array}$ & $\begin{array}{l}0.101^{* *} \\
(0.021)\end{array}$ & $\begin{array}{l}0.081^{* *} \\
(0.019)\end{array}$ & $\begin{array}{l}0.083^{* *} \\
(0.019)\end{array}$ \\
\hline $\begin{array}{l}\text { Grandfather's education } \\
\times \text { Purchase Degree }\end{array}$ & & & & $\begin{array}{l}-0.028 \\
(0.066)\end{array}$ \\
\hline Father's age at birth & $\begin{array}{c}-0.002^{* *} \\
(0.001)\end{array}$ & $\begin{array}{c}-0.002^{* *} \\
(0.001)\end{array}$ & $\begin{array}{c}-0.002^{* *} \\
(0.001)\end{array}$ & $\begin{array}{c}-0.002^{* *} \\
(0.001)\end{array}$ \\
\hline Mother's age at death & $\begin{array}{l}0.001^{*} \\
(0.000)\end{array}$ & $\begin{array}{l}0.001^{*} \\
(0.000)\end{array}$ & $\begin{array}{l}0.001^{*} \\
(0.000)\end{array}$ & $\begin{array}{l}0.001^{*} \\
(0.000)\end{array}$ \\
\hline Mother rank is one & $\begin{array}{c}-0.056^{* *} \\
(0.020)\end{array}$ & $\begin{array}{c}-0.078^{* *} \\
(0.023)\end{array}$ & $\begin{array}{c}-0.070^{* *} \\
(0.021)\end{array}$ & $\begin{array}{c}-0.069^{* *} \\
(0.021)\end{array}$ \\
\hline Observations & 4,806 & 4,806 & 4,806 & 4,806 \\
\hline R-squared & 0.101 & 0.131 & 0.262 & 0.262 \\
\hline
\end{tabular}

Notes: Dep. Var.: Education. Results by OLS. Brothers is number of brothers divided by 10 . Birth year is man's birth year divided by 1,000 . Robust standard errors clustered by household in parentheses. **/*/+ significant at $1 \% / 5 \% / 10 \%$ level. 
Table H. Quantity-quality relationship in early versus late Qing - Probit results

\begin{tabular}{|c|c|c|c|c|c|c|c|c|c|}
\hline & (1) & $(2)$ & (3) & (4) & (5) & (6) & (7) & (8) & (9) \\
\hline & $<1780$ & $\geq 1780$ & $<1785$ & $\geq 1785$ & $<1790$ & $\geq 1790$ & $<1795$ & $\geq 1795$ & $<1800$ \\
\hline Brothers & $\begin{array}{l}-0.777^{\star} \\
(0.357)\end{array}$ & $\begin{array}{l}-0.258 \\
(0.502)\end{array}$ & $\begin{array}{l}-0.865^{\star} \\
(0.347)\end{array}$ & $\begin{array}{l}-0.109 \\
(0.512)\end{array}$ & $\begin{array}{c}-0.973^{* *} \\
(0.338)\end{array}$ & $\begin{array}{c}0.055 \\
(0.533)\end{array}$ & $\begin{array}{c}-0.968^{* *} \\
(0.329)\end{array}$ & $\begin{array}{c}0.092 \\
(0.551)\end{array}$ & $\begin{array}{r}-1.032^{* *} \\
(0.327)\end{array}$ \\
\hline Trend & $\begin{array}{c}-1.672 \\
(1.171)\end{array}$ & $\begin{array}{l}-1.356 \\
(2.514)\end{array}$ & $\begin{array}{c}-1.483 \\
(1.111)\end{array}$ & $\begin{array}{l}-0.333 \\
(2.715)\end{array}$ & $\begin{array}{l}-1.546 \\
(1.072)\end{array}$ & $\begin{array}{c}0.863 \\
(2.870)\end{array}$ & $\begin{array}{l}-2.090^{*} \\
(1.002)\end{array}$ & $\begin{array}{l}-1.316 \\
(3.356)\end{array}$ & $\begin{array}{l}-2.069^{*} \\
(0.954)\end{array}$ \\
\hline $\begin{array}{l}\text { Father age at } \\
\text { birth }\end{array}$ & $\begin{array}{c}-0.020^{\star *} \\
(0.007)\end{array}$ & $\begin{array}{l}-0.007 \\
(0.006)\end{array}$ & $\begin{array}{c}-0.020^{\star *} \\
(0.007)\end{array}$ & $\begin{array}{l}-0.006 \\
(0.007)\end{array}$ & $\begin{array}{l}-0.022^{* *} \\
(0.006)\end{array}$ & $\begin{array}{l}-0.002 \\
(0.007)\end{array}$ & $\begin{array}{c}-0.021^{* *} \\
(0.006)\end{array}$ & $\begin{array}{l}-0.003 \\
(0.007)\end{array}$ & $\begin{array}{r}-0.022^{* *} \\
(0.006)\end{array}$ \\
\hline $\begin{array}{l}\text { Mother age at } \\
\text { death }\end{array}$ & $\begin{array}{l}0.007^{*} \\
(0.003)\end{array}$ & $\begin{array}{l}0.010^{* *} \\
(0.003)\end{array}$ & $\begin{array}{l}0.006^{*} \\
(0.003)\end{array}$ & $\begin{array}{l}0.012^{* *} \\
(0.004)\end{array}$ & $\begin{array}{l}0.007^{*} \\
(0.003)\end{array}$ & $\begin{array}{l}0.012^{\star *} \\
(0.004)\end{array}$ & $\begin{array}{l}0.007^{* *} \\
(0.003)\end{array}$ & $\begin{array}{l}0.011^{* *} \\
(0.004)\end{array}$ & $\begin{array}{l}0.008^{* *} \\
(0.003)\end{array}$ \\
\hline $\begin{array}{l}\text { Father's } \\
\text { education }\end{array}$ & $\begin{array}{l}0.853^{* *} \\
(0.112)\end{array}$ & $\begin{array}{l}0.750^{* *} \\
(0.131)\end{array}$ & $\begin{array}{l}0.828^{* *} \\
(0.107)\end{array}$ & $\begin{array}{l}0.752^{\star *} \\
(0.138)\end{array}$ & $\begin{array}{l}0.769^{* *} \\
(0.105)\end{array}$ & $\begin{array}{l}0.854^{\star *} \\
(0.143)\end{array}$ & $\begin{array}{l}0.764^{* *} \\
(0.103)\end{array}$ & $\begin{array}{l}0.884^{* *} \\
(0.150)\end{array}$ & $\begin{array}{l}0.750^{* *} \\
(0.101)\end{array}$ \\
\hline $\begin{array}{l}\text { Grandfather's } \\
\text { education }\end{array}$ & $\begin{array}{l}0.517^{* *} \\
(0.106)\end{array}$ & $\begin{array}{l}0.683^{* *} \\
(0.121)\end{array}$ & $\begin{array}{l}0.544^{* *} \\
(0.101)\end{array}$ & $\begin{array}{l}0.647^{* *} \\
(0.127)\end{array}$ & $\begin{array}{l}0.528^{* *} \\
(0.099)\end{array}$ & $\begin{array}{l}0.680^{* *} \\
(0.132)\end{array}$ & $\begin{array}{l}0.504^{* *} \\
(0.098)\end{array}$ & $\begin{array}{l}0.707^{* *} \\
(0.135)\end{array}$ & $\begin{array}{l}0.504^{* *} \\
(0.096)\end{array}$ \\
\hline $\begin{array}{l}\text { Mother's rank } \\
\text { is one }\end{array}$ & $\begin{array}{c}-0.429^{\star \star} \\
(0.131)\end{array}$ & $\begin{array}{c}-0.392^{\star *} \\
(0.140)\end{array}$ & $\begin{array}{c}-0.408^{\star \star} \\
(0.128)\end{array}$ & $\begin{array}{c}-0.418^{\star *} \\
(0.143)\end{array}$ & $\begin{array}{c}-0.420^{\star *} \\
(0.125)\end{array}$ & $\begin{array}{c}-0.390^{\star *} \\
(0.148)\end{array}$ & $\begin{array}{c}-0.435^{\star \star} \\
(0.123)\end{array}$ & $\begin{array}{l}-0.354^{\star} \\
(0.153)\end{array}$ & $\begin{array}{c}-0.435^{\star \star} \\
(0.122)\end{array}$ \\
\hline $\begin{array}{l}\text { Brothers } \\
\text { marginal effect }\end{array}$ & $-0.079^{*}$ & -0.017 & $-0.088^{*}$ & -0.007 & $-0.098^{\star *}$ & 0.003 & $-0.094^{\star \star}$ & 0.006 & $-0.098^{\star *}$ \\
\hline \multirow[t]{3}{*}{ Observations } & 3,708 & 3,843 & 3,930 & 3,625 & 4,175 & 3,384 & 4,464 & 3,098 & 4,782 \\
\hline & (10) & (11) & (12) & (13) & (14) & (15) & (16) & (17) & (18) \\
\hline & $\geq 1800$ & $<1805$ & $\geq 1805$ & $<1810$ & $\geq 1810$ & $<1815$ & $\geq 1815$ & $<1820$ & $\geq 1820$ \\
\hline Brothers & $\begin{array}{c}0.251 \\
(0.554)\end{array}$ & $\begin{array}{c}-1.047^{* *} \\
(0.327)\end{array}$ & $\begin{array}{c}0.403 \\
(0.569)\end{array}$ & $\begin{array}{c}-1.000^{* *} \\
(0.323)\end{array}$ & $\begin{array}{c}0.482 \\
(0.603)\end{array}$ & $\begin{array}{l}-0.774^{*} \\
(0.326)\end{array}$ & $\begin{array}{l}0.156 \\
(0.693)\end{array}$ & $\begin{array}{l}-0.675^{*} \\
(0.316)\end{array}$ & $\begin{array}{l}-0.092 \\
(0.634)\end{array}$ \\
\hline Trend & $\begin{array}{l}-1.685 \\
(3.668)\end{array}$ & $\begin{array}{l}-2.159^{*} \\
(0.913)\end{array}$ & $\begin{array}{l}-3.829 \\
(4.214)\end{array}$ & $\begin{array}{l}-2.111^{*} \\
(0.888)\end{array}$ & $\begin{array}{l}-4.839 \\
(4.678)\end{array}$ & $\begin{array}{c}-1.683+ \\
(0.875)\end{array}$ & $\begin{array}{l}-0.169 \\
(5.503)\end{array}$ & $\begin{array}{l}-1.677^{*} \\
(0.849)\end{array}$ & $\begin{array}{l}-0.662 \\
(7.422)\end{array}$ \\
\hline $\begin{array}{l}\text { Father age at } \\
\text { birth }\end{array}$ & $\begin{array}{c}0.001 \\
(0.007)\end{array}$ & $\begin{array}{c}-0.022^{* *} \\
(0.006)\end{array}$ & $\begin{array}{c}0.003 \\
(0.007)\end{array}$ & $\begin{array}{c}-0.022^{* *} \\
(0.006)\end{array}$ & $\begin{array}{c}0.005 \\
(0.008)\end{array}$ & $\begin{array}{l}-0.020^{* *} \\
(0.006)\end{array}$ & $\begin{array}{c}0.008 \\
(0.008)\end{array}$ & $\begin{array}{l}-0.018^{\star *} \\
(0.006)\end{array}$ & $\begin{array}{c}0.010 \\
(0.010)\end{array}$ \\
\hline $\begin{array}{l}\text { Mother age at } \\
\text { death }\end{array}$ & $\begin{array}{c}0.009^{*} \\
(0.004)\end{array}$ & $\begin{array}{l}0.008^{\star *} \\
(0.003)\end{array}$ & $\begin{array}{l}0.009^{*} \\
(0.004)\end{array}$ & $\begin{array}{l}0.009^{\star *} \\
(0.003)\end{array}$ & $\begin{array}{c}0.010^{*} \\
(0.004)\end{array}$ & $\begin{array}{l}0.008^{\star *} \\
(0.003)\end{array}$ & $\begin{array}{l}0.011^{*} \\
(0.004)\end{array}$ & $\begin{array}{l}0.008^{\star *} \\
(0.003)\end{array}$ & $\begin{array}{c}0.012^{*} \\
(0.005)\end{array}$ \\
\hline $\begin{array}{l}\text { Father's } \\
\text { education }\end{array}$ & $\begin{array}{l}0.907^{* *} \\
(0.155)\end{array}$ & $\begin{array}{l}0.725^{\star *} \\
(0.099)\end{array}$ & $\begin{array}{l}1.020 * * \\
(0.157)\end{array}$ & $\begin{array}{l}0.726^{\star *} \\
(0.097)\end{array}$ & $\begin{array}{l}1.066^{\star *} \\
(0.158)\end{array}$ & $\begin{array}{l}0.757^{\star *} \\
(0.097)\end{array}$ & $\begin{array}{l}1.012^{\star *} \\
(0.191)\end{array}$ & $\begin{array}{l}0.753^{\star *} \\
(0.095)\end{array}$ & $\begin{array}{l}1.183^{* *} \\
(0.202)\end{array}$ \\
\hline $\begin{array}{l}\text { Grandfather's } \\
\text { education }\end{array}$ & $\begin{array}{l}0.691^{* *} \\
(0.137)\end{array}$ & $\begin{array}{l}0.525^{* *} \\
(0.093)\end{array}$ & $\begin{array}{l}0.630^{* *} \\
(0.141)\end{array}$ & $\begin{array}{l}0.541^{* *} \\
(0.091)\end{array}$ & $\begin{array}{l}0.578^{* *} \\
(0.142)\end{array}$ & $\begin{array}{l}0.549^{\star *} \\
(0.089)\end{array}$ & $\begin{array}{l}0.551^{* *} \\
(0.161)\end{array}$ & $\begin{array}{l}0.558^{\star *} \\
(0.087)\end{array}$ & $\begin{array}{l}0.531^{* *} \\
(0.178)\end{array}$ \\
\hline $\begin{array}{l}\text { Mother's rank } \\
\text { is one }\end{array}$ & $\begin{array}{l}-0.339^{*} \\
(0.151)\end{array}$ & $\begin{array}{c}-0.435^{\star *} \\
(0.121)\end{array}$ & $\begin{array}{l}-0.344^{*} \\
(0.150)\end{array}$ & $\begin{array}{c}-0.415^{\star *} \\
(0.120)\end{array}$ & $\begin{array}{l}-0.386^{*} \\
(0.155)\end{array}$ & $\begin{array}{c}-0.439^{* *} \\
(0.118)\end{array}$ & $\begin{array}{l}-0.349^{*} \\
(0.160)\end{array}$ & $\begin{array}{c}-0.435^{\star *} \\
(0.114)\end{array}$ & $\begin{array}{l}-0.307 \\
(0.199)\end{array}$ \\
\hline $\begin{array}{l}\text { Brothers } \\
\text { marginal effect }\end{array}$ & 0.016 & $-0.097^{\star *}$ & 0.026 & $-0.090^{\star *}$ & 0.032 & $-0.070^{*}$ & 0.010 & $-0.060^{\star}$ & -0.006 \\
\hline Observations & 2,786 & 5,131 & 2,441 & 5,452 & 2,141 & 5,741 & 1,856 & 6,045 & 1,437 \\
\hline
\end{tabular}


(1)

Baseline
(2)

Generalized

Time Trend
(3)

Educated and

Purchased

Degree

$-0.017$

$(0.047)$

$(0.044)$

$(0.044)$

Brothers x Purchased Degree

Trend

Father's education

Grandfather's education

Father's age at birth

Mother's age at death

Mother rank is one

Observations
$-0.076$

$(0.279)$

$0.160^{\star \star}$

$(0.035)$

$0.074^{\star \star}$

$(0.020)$

0.000

$(0.001)$

0.000

$(0.000)$

$-0.031+$

(0.018)

2,850 $0.159^{\star *}$

(0.035)

$0.074^{\star *}$

$(0.020)$

0.000

$(0.001)$

0.000

$(0.000)$

$-0.030+$

(0.018)
(4)

Educated and

Purchased

Degree

$-0.044$

$(0.044)$

$2.077^{* *}$

(0.331)

0.082

$(0.283)$

0.000

$(0.001)$

0.000

$(0.000)$

$0.196^{* *}$

$(0.037)$

$0.076^{\star \star}$

(0.020)

$-0.032+$

(0.018)

Notes: Dependent variable is Education. Estimation by OLS. Brothers is number of brothers divided by 10 . Trend is man's birth date. Column 2 includes decade fixed effects. Robust standard errors clustered on household in parentheses. ${ }^{* *} / * /+$ means significant at the $1 \% / 5 \% / 10 \%$ level. 
Figure A. Quantity-quality relationship in early versus late Qing: nearest-neighbor matching for alternative time breakpoints

Excess number of brothers of uneducated compared to educated men 0.35

0.3

0.25

0.2

0.15

0.1

0.05

0
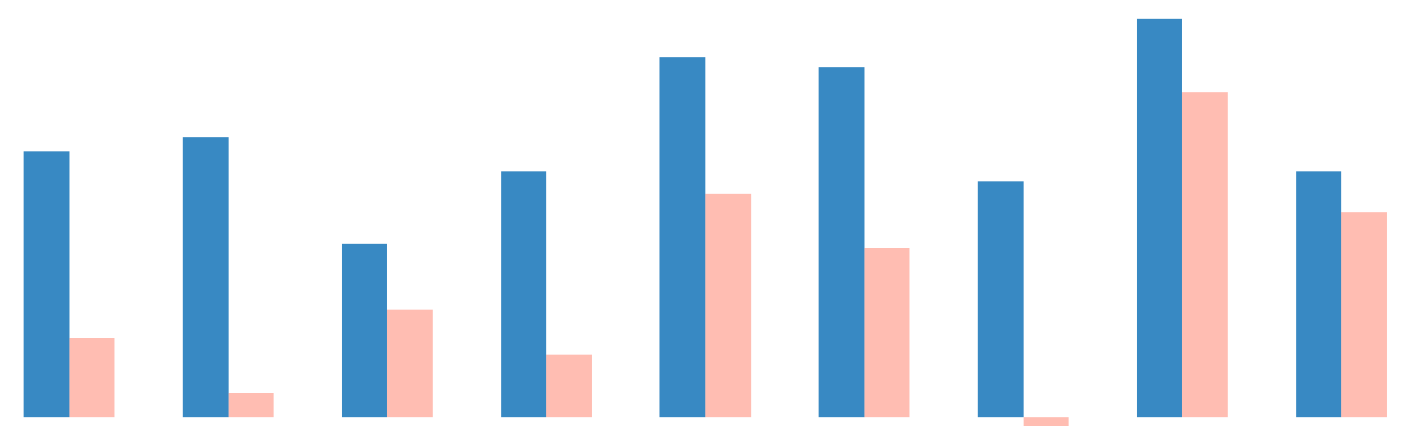

$-0.05$

$-0.1$

Difference in early Qing always significant

$-0.15$ Difference in late Qing never significant

1800

1805

1810

1815

1820

Early Qing $\square$ Late Qing 